Alma Mater Studiorum - Università di Bologna DEPARTMENT OF ECONOMICS

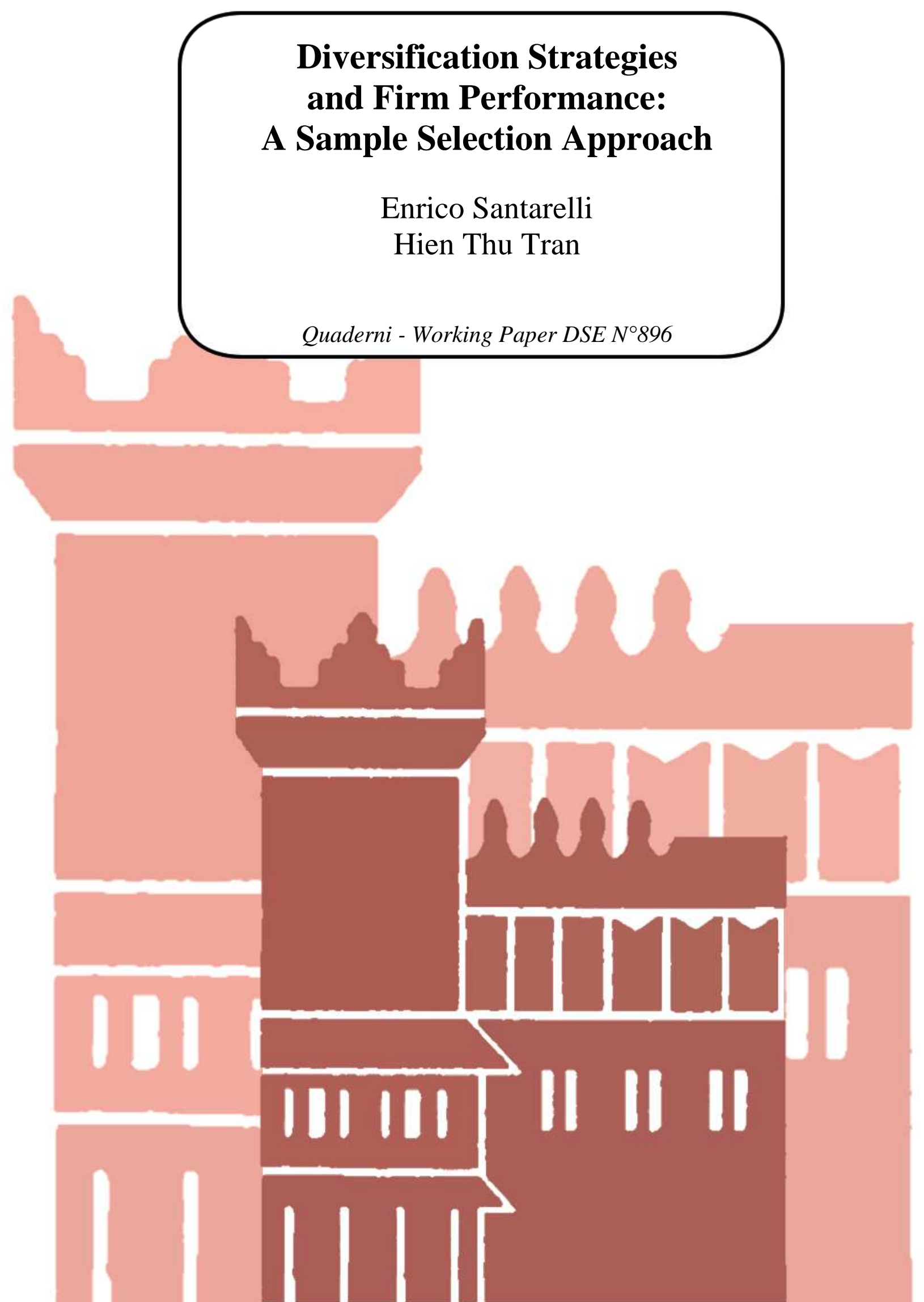




\title{
Diversification Strategies and Firm Performance: A Sample Selection Approach
}

\author{
Enrico Santarelli \\ University of Bologna, Department of Economics; Piazza Scaravilli, 2 - 40126 Bologna, Italy; \\ tel. +39051 2098487; e-mail: enrico.santarelli@unibo.it
}

\section{Hien Thu Tran}

University of Bologna, Department of Economics Piazza Scaravilli, 2 - 40126 Bologna, Italy; e-mail: thuhien.tran@unibo.it

\begin{abstract}
$\underline{\text { Abstract: }}$
This paper is based upon the assumption that firm profitability is determined by its degree of diversification which in turn is strongly related to the antecedent decision to carry out diversification activities. This calls for an empirical approach that permits the joint analysis of the three interrelated and consecutive stages of the overall diversification process: diversification decision, degree of diversification, and outcome of diversification. We apply parametric and semiparametric approaches to control for sample selection and endogeneity of diversification decision in both static and dynamic models. After controlling for industry fixed-effects, empirical evidence from firm-level data shows that diversification has a curvilinear effect on profitability: it improves firms' profit up to a point, after which a further increase in diversification is associated with declining performance. This implies that firms should consider optimal levels of product diversification when they expand product offerings beyond their core business. Other worth-noting findings include: (i) factors stimulating firms to diversify do not necessarily encourage them to extend their diversification strategy; (ii) firms which are endowed with highly skilled human capital are likely to successfully exploit diversification as an engine of growth; (iii) while industry performance does not influence profitability of firms, it impacts their diversification decision and degree.
\end{abstract}

Keywords: Diversification; Firm performance; panel data; sample selection; parametric and semiparametric models.

JEL Codes: L21; L25; C14; C23. 


\section{Introduction}

What determines the optimal boundaries of the firm across industries? How does a firm expand from its core business into other product markets? These questions have raised substantial research interests from the initial landmark article The Nature of the Firm by Coase (1937) and book The Theory of the Growth of the Firm by Penrose (1959). Since then, different theories (resource-based view, transaction cost, agency theory, etc.) have been proposed to explain firm diversification (Chandler, 1962, Berry, 1975, Rumelt, 1974, Andrews, 1980). The early industrial organization literature has argued that no significant relationship exists between diversification and performance, meaning that, when entering new markets, existing firms have no special advantages (see, e.g., Gort, 1962, Arnould, 1969, Markham, 1973). More recently, researchers have shown that diversification generates multiple outcome directions depending on the degree of relatedness of a firm's diversification activities (Palich et al., 2000; Qian, 2002). These studies share one common finding that the diversification/performance relationship follows a non-linear pattern: they are positively related up to a point, after which a further increase in diversification is associated with declining performance.

Notwithstanding this change of perspective, scholars have so far mostly focused on the single causal effect of degree of diversification relatedness on firms' subsequent performance, neglecting the whole diversification process that firms involve in until the final diversification outcome is recognized. The important question left unanswered is therefore: why not all firms engage in diversification activities or receive equally positive outcomes from their diversification strategies? Exploration of antecedent factors determining a firm's likelihood to diversify as well as how much it can diversify upon its green-light decision might lead to an answer.

First, we argue that it may not be appropriate to analyse the diversification/performance relationship in a single-equation framework, since it is strongly related to the pre-determined factors that induce firms to engage in diversification. Thus, we investigate the whole diversification process in three interrelated and consecutive equations: diversification decision (what determines a firm to diversify?); diversification degree (once a firm decides to diversify, what determines the degree of its diversification relatedness?); and diversification outcome (how does a firm's diversification degree influence its profitability?). Since the three equations are by nature interrelated, we take into consideration the possibility that their disturbances are correlated, and thus, we need to be careful in choosing the right estimation methodology given the existence of unobservable characteristics that affect the three stages under study.

Second, we are aware that ANOVAs or cross-sectional least squares regressions are inadequate to study the relationship between diversification and performance, since these methodological approaches treat the decision to diversify exogenously, i.e. firm-level and industry-level characteristics as well as the influence of the external environment are implicitly assumed not to have any effect on firms' diversification strategies. Consistent with Maksimovic and Phillips (2002) and Lang and Stulz (1994) among others, who show that firm and industry characteristics influence a firm's decision to diversify, we take into account the sample selection and endogeneity issues from correlated disturbances by applying advanced parametric and semiparametric estimation methods for both static and dynamic treatments of firm-level panel data. Initially, sample selection will be tested and corrected by four estimation approaches: the standard Heckman's two-stage method, the Vella (1998) and Wooldridge (1995) parametric 
approach, Heckman et al.'s (1998) kernel-based propensity score matching, the Semykina and Wooldridge (2010) model. Each of these approaches is employed in the first two stages: a binary choice selection equation determining whether or not the firm diversifies, and then conditional on its diversification decision, we observe its degree of relatedness to the firm's core business; subsequently, endogeneity of diversification degree is controlled in the firm performance equation, under the hypothesis that unobserved individual-level and firm-level characteristics might influence both firms' diversification decision and their subsequent profitability (given their diversification decision and diversification degree choice). For this purpose we apply the GMM and Arellano-Bond (1991) difference GMM estimation approach for both static and dynamic treatments.

Apart from the novelty of investigating the diversification/performance relationship in a comprehensive three-stage process and controlling for selectivity and endogeneity issues with advanced methodological approaches for firm-level panel data, this work makes another contribution as a pioneer in studying diversification activities of firms in a transition country. We argue that diversification can be a growth strategy also for firms in transition countries. We rely on the dataset of the whole population of firms in Binh Duong, the most competitive province in Vietnam after excluding state-owned and foreign firms, which is extracted from the annual enterprise survey of Vietnam General Statistics House.

Key findings of the present study are: (i) factors stimulating firms to diversify do not necessarily influence their diversification degree to the same extent of sign and magnitude; (ii) firms with higher debt ratio are more likely to diversify and with stronger degree; (iii) export firms have more opportunities to recognize diversification activities, but do not necessarily diversify at stronger degree than non-export firms; (iv) diversification has a curvilinear effect on firm-level profitability: product diversification improves firms' profit up to a point, after which a further increase in diversification is associated with declining performance; (v) firms endowed with highly skilled human capital are likely to successfully exploit diversification as an engine of growth; (vi) low industry profitability significantly stimulates firms to diversify into other business sectors, but does not have any impact on their overall performance.

The paper is structured as follows. Section 2 summarizes the theoretical discussion on product diversification and its relationship to the performance of firms. Section 3 gives an overview of the dataset that we use for this paper. Section 4 presents the operationalization of variables adopted together with their descriptive statistics and correlation matrix. Section 5 develops the approach(es) that we apply to obtain final empirical estimation after relevant tests for the existence of sample selection and endogeneity. Section 6 discusses the estimation results, and finally, section 7 gives some concluding remarks for policy implication and future research.

\section{Literature discussion}

There have been a number of researchers proposing definitions and measures of product diversification. Ansoff (1965), defines a diversification strategy as the entry into new markets with new products, whereas Kamien and Schwartz (1975) define it as a firm's degree of product and market involvement. For Jacquemin and Berry (1979), product diversity refers to the degree 
of relatedness among various product segments. Following Rumelt (1974), several scholars ${ }^{1}$ view diversification as the strategy of adding related or similar product/service lines to existing core business, either through acquisition of competitors or through internal development of new products/services, which implies increase in available managerial competence within the firm.

In this sense, diversification is a matter of degree of relatedness among the activities carried out by a firm. Product relatedness is defined as the extent to which a firm's different lines of business are linked by a common skill, market, purpose, or resource (Rumelt, 1974; Luo, 2002). Recent studies have attempted to examine diversification patterns from underlying resource requirements: the degree to which two industries use the same types and proportions of human expertise (Farjoun, 1994) or rely on the same inflows of technology (Robins and Wiersema, 1995). However, these studies characterize resources only at the industry level, which limits the ability to address issues relating to heterogeneity in firms' resource bases. Thus, in practice, diversification is normally measured as the number of activities a firm undertakes in different sectors. The degree of relatedness is then measured with reference to the system of standard industrial classification (SIC codes). While this type of measure incurs inherent limitations for not taking into account internal managerial effort or resource requirements underlying observable diversification activities and relying on proximity among SIC codes (Silverman, 1999), it has still been applied commonly in empirical parts of this work due to its availability and straight forward nature.

Montgomery (1994) distinguishes three motivations for diversification: the search for market power; the solution to agency problems; and the application of bundles of resources to attain a competitive advantage (resource-based view). Focusing on the determinants of the distribution of the firm's activities over industries beside its primary focus on vertical integration, transaction cost economics suggests that diversification is an alternative contractual method by which a firm can exploit its surplus resources (Silverman, 1999). By the same token, Grossmann (2007) submits that diversification may be a mean to extend the boundaries of a firm in the presence of internal coordination problems, which naturally arise in large firms. Multiproduct firms can increase their market power by cross subsidisation activities, i.e. market strength in one particular industry may be used to sustain low price strategies in other markets. Similarly, Teece et al. (1994), Christensen and Foss (1997), Foss and Christensen (2001) agree that diversified firms can create positive spillovers since the value of resources in one industry increases due to investment in another industry. Finally, the internal capital markets hypothesis indicates that diversified firms arise when financial market imperfections force managers to allocate funds more efficiently than the external capital market (Klein and Lien, 2009).

Usually, firms diversify as long as they see the opportunity to consolidate their market power, which predicts a linearly positive relationship between diversification and profitability. Diversification strategies undertaken by growth-oriented managers may both well exploit scope economies and at the same time increase firms' market power. An efficient way to increase firms' market power is the multimarket contact hypothesis (Bernheim and Whinston, 1990; Scott, 1993; Spagnolo, 1999), following which firms meeting in several markets have a greater incentive to network with each other in order to sustain collective power. By diversifying in a similar way (in order to exploit cost synergies), a group of firms might create and consolidate a situation of

${ }^{1}$ Such as Markides (1995), Markides and Williamson (1994), Tallman and Li (1996), Nachum (1999). 
multimarket contacts where collusive practices are more likely to emerge. With respect to the effects, good performance outcomes for diversified firms are consistent with both market power, i.e. firms meeting in several markets co-ordinate to increase their bargaining power on setting higher prices, and efficiency reasons, i.e. firms diversify to exploit positive cost externalities.

Whereas the market power search approach is consistent with a linear positive relationship between diversification and profitability, the agency approach predicts a negative relationship as managers use free cash flow for the sake of their own goals. This leads to considering diversification in large firms as a result of the separation between ownership and control which induces managers to pursue their own objectives at the expense of shareholders. Hoskisson and Hitt (1990) suggest that diversification, firm size, and executive compensations are highly correlated to the extent that diversification provides benefits to managers that are unavailable to investors. Diversification can also lead to the problem of moral hazard due to conflict of interest between managers having interest in costly diversification as a form of compensation and investors preferring to concentrate on the core business to maximize their returns (Bhide, 1990).

Third, the same negative relationship between diversification and firm performance is also predicted by the resource-based view (Penrose, 1959). Firm is seen as a collection of sticky and imperfectly imitable resources or capabilities which strengthens its competition against its competitors (Barney, 1986). The deployment of surplus resources and free cash flows is one of the prime motives of diversification (Hoskisson and Hitt, 1990). However, asset specificity embedded in firms' resources on one hand brings sustainable competitive power for their owner relative to competitors, but on the other hand acts as a challenge impeding firm's ability to transfer resources to new applications or "transplant" them in a new context (Montgomery and Wernerfelt, 1988). Therefore, the value of diversification will depend on the complementarities existing between internal resources and the business/industry that the firm enters, as well as the diversifying mode that it chooses. This opens the way to several empirical predictions revolving around the concept of relatedness of diversification activities: the more closely those activities are related or complementary, the more profitable diversification is expected to be. Regrettably, the resource-based approach to diversification has generally not considered the possibility that firms can exploit resources through market arrangements rather than through expansion of corporate boundaries. Although resources can be exploited through contracts, the regularlyassumed valuable, rare, inimitable, and difficult-to-imitate resources are too "asset specific" (Williamson, 1985) to be contracted in market transactions.

Finally, researchers of transaction cost economics suggest that diversification is an alternative contractual method by which a firm can exploit its resources (Silverman, 1999). However, no matter how business activities are related, the transfer of product and process technology among different industries with different characteristics normally requires certain modification and adjustment, which incurs varying degree of transaction costs as a result (Qian, 2002). When a firm moves into a market with only a weak connection to its primary line of business (unrelated diversification), it often lacks the know-how and managerial resources to prevail against the competition in this new industry. Diversification beyond a certain degree raises internal governance and administration costs to the point that performance suffers (Jones and Hill, 1988). Thus, many of the most significant failures of diversification can be traced to the failure of achieving sufficient relatedness between business sectors (Grant, 1988). The related 
hypothesis in transaction cost approach claims that multi-business firms holding portfolios of similar related business might obtain efficiency advantages unavailable to non-diversified firms or firms with unrelated portfolios. According to Lien and Klein (2006), economic sense of relatedness implies that resources in one industry are substitutes for, or complements to, resources in another industry. Whether the firm successfully integrates new business sectors depends on the comparative costs and benefits of contracting, not on the underlying production technology. Iacobucci and Rosa (2005) suggest that group formation offers a solution to problems created by market imperfections that increase transaction costs.

Empirically, the impact of diversification on firm performance is mixed (Datta et al., 1991; Hoskisson and Hitt, 1990). Some studies claim diversifying into related product markets produces higher returns than into unrelated markets, others propose that less diversified firms perform better than highly diversified firms (Christensen and Montgomery, 1981; Rumelt, 1974, 1982). Some claim that the economies in integrating operations and core skills obtained in related diversification outweigh the costs of internal capital markets and smaller variances in sales generated by unrelated diversification (Datta et al., 1991). While Prahalad and Bettis (1986) claim that it is not product-market diversity but the strategic logic applied by managers that determines the effect of diversification on performance, Montgomery (1985) argues that it is not management conduct, but industry structure that governs firm performance.

Vannoni (2004) observes that diversification is normally approached focusing either on the synergies exploited by diversified firms and on the optimal organizational structure for managing a multiproduct firm (strategic management approach) or on the relationships between market/industry structure (industrial organization approach). In each discipline the empirical literature has grown with scarce contacts with the other one. Thus, the need to construct and/or reinforce an interdisciplinary dialogue is particularly evident in this area of studies.

With respect to the strategic management approach, corporate strategies despite being based on various sets of management guidelines addressing the question "what is the appropriate scale and scope of the firm?", all converge in dealing with conflicting demands of synergies and responsiveness with respect to allocating resources (Wit and Meyer, 2005). Successful corporate strategies are the result of organizational capabilities or competencies that allow firms to exploit potential synergies that large size or diversity can offer. On one hand, the synergy of interrelated businesses within a diversified firm brings in the benefit of economies of scope which arise from sharing both common tangible inputs such as markets, distribution systems, product and process technologies, or manufacturing facilities (Ansoff, 1965; Rumelt, 1974; Teece, 1980), and intangible assets such as brand names and know-how (Qian, 1997), managerial capabilities and routines and repertoires (Prahalad and Bettis, 1986; Grant, 1988). The more interrelated the businesses of a firm, the greater the potential for organizational synergy (Rumelt, 1974; Salter and Weinhold, 1981). On the other hand, synergy has harmful effects owing to responsiveness, such as higher governance costs, slower decision-making, strategy incongruence, dysfunctional control, and dulled incentives (Wit and Meyer, 2005). Thus, the fundamental challenge facing corporate diversification is the conflicting forces stemming from synergy and responsiveness, or as described by Dess et al. (2003), "managing the conflict between the new and old (business activities) and overcoming the inevitable tensions that such conflict produces for management". Nevertheless, empirical studies of synergy and responsiveness only enable us to state whether 
diversification has a positive (due to synergy) or a negative (due to responsiveness) effect on firm performance, or which type of diversification, related or unrelated, is more beneficial. With respect to the curvilinear relationship between diversification and firm performance, we cannot explain to what extent the positive effect from synergy fades away and will be replaced by the negative effect of responsiveness, or why moderate levels of diversification yield higher levels of performance than either limited or extensive diversification (Tran and Zaninotto, 2012).

With respect to the industrial organization approach, diversification as the proxy for economies of scope is investigated in relation to firms' innovative capabilities. Firms are assumed to have different innovative capabilities that lead them to pursue different types of product diversifications (Cohen and Klepper, 1992). A firm with a diversified portfolio of products may be better positioned to determine the general applicability of new ideas than a firm with a narrower portfolio of products, because it can capture internal knowledge spillovers. Indeed, firms selling only one category of products are less likely to engage in R\&D than those selling a broader range of products (Piga and Vivarelli, 2004). Given the same competencies for the production and delivery of core products, together with the same incentives to diversify, firms possessing more dynamic capabilities will be more likely to expand their product scope (Doving and Gooderham, 2008).

Regardless of which disciplinary and theoretical perspective one adopts, most studies support a non-linear relationship between diversification and profitability (for a review, see Palich et al., 2000). Appropriateness of product diversity is judged by a balance between economies of scope and diseconomies of scale, which indicates a limit on how much a firm can diversify. If a firm goes beyond this point, its market value suffers (Markides, 1992). Related diversification enables corporations to perform better if they expand their stocks of strategic assets efficiently and in consistency (Teece et al., 1994). Among the studies including measures of relatedness in order to discriminate between type and level of diversification, Vannoni (2000) presents evidence for a sample of Italian firms that irrespective of the number of industries in which they are active, they reach good performance results thanks to the relatedness of their diversifications strategies.

Based on the above survey of the relevant literature, we propose the following proposition on diversification activities of firms:

Proposition: Product diversification has a curvilinear relationship with profitability: positive when firms expand into industries related to their original industries and negative when they diversify beyond their original industries.

\section{Data description}

Panel firm-level data from 2001 to 2006 were extracted from the GSO (General Statistics Office) of Vietnam's database of annual national enterprise surveys. Since we wished to omit the effects of the unique macro-economic and institutional environment of each province, only firms located in the province of Binh Duong were used for the empirical analysis. In other words, we use the whole population of firms in an administrative unit, rather than samples of representative firms from different ones, for the analysis ${ }^{2}$.State-owned monopolistic firms (electricity, water

\footnotetext{
${ }^{2}$ The rationale to select for analysis only observations in one province is: (i) to isolate the effect of institutional and macroeconomic features which are assumed to be homogenous to every firm within one province; (ii) to control for the influence of
} 
supply, post and telecommunications) and foreign-invested firms, which are generally largescaled and over-capitalized, were removed from the analysis to avoid extreme outliers. Thus, the final sample consists only of private firms.

Binh Duong was chosen because of its competitive and dynamic market ${ }^{3}$. The firm-level dataset includes segment data (ISIC code, segment sales, assets), accounting data (debts, revenue, profit, assets), basic demographic data (year of inception, ownership structure, size of labor force, technical personnel), and business owners' individual-level information (gender, age, education levels). Our final sample only comprises multi-segment firms with data available at both firm and segment levels. Since we investigate the whole diversification process overtime, from decision stage to final outcome, only firms established before 2001 and still operating in 2006 were used for analysis. The final dataset forms a balanced panel of 5580 observations consisting of 903 firms observed continuously over a period of 6 years.

\section{Variables and Descriptive Statistics}

Firm performance: Various measures of firm performance produce strikingly different results (for a review, see Deeds et al., 1998). For instance, R\&D-intensive companies may have low profits during the developmental stage, but this does not mean that their value, i.e., the amount of shareholder wealth, is equivalently low. Similarly, recent analysis has found a negative correlation between sales growth and performance measures of earnings per share, return on equity, and return on investment (Murphy et al., 1996). In this paper, the profitability measures employed are return on sales (ROS) and return on investment (ROI). They indicate how net income is earned from each thousand Vietnamese dong (VND) of sales and total investment respectively. ROS is the ratio between after-tax profits and sales; ROI is the ratio between after-tax profits and total annual investment. The rationales for using ROS and ROI, rather than the widely-used logarithm of profit or ROA (return on assets) are: logarithm of profit excludes firms operating at loss (negative profit) from the analysis, whereas sales and annual investment are generally expressed in more current monetary terms than are assets, which would carry book values and require a longer time frame of availability (Geringer et al., 1989).

We focus our analysis on firm performance equation with ROI as dependent variable. ROS estimation is placed in Appendix $\mathrm{C}$ for benchmark purpose. Our rationales for choosing ROI as the main dependent variable can be explained as follows. Diversified firms normally obtain sales generated from different sources. As we mentioned above, firms may diversify into a new business sector in order to balance out the loss or reducing profit that they incur from their current industries; thus, a low ROS does not mean their diversification activities are not successful. However, ROI captures the return on firms' annual invested capital into diversification activities. It shows us directly the performance of diversification investment by excluding the impacts of other revenue sources. There is also no evidence that firms considered in our analysis undertake their diversification policy by setting up independent businesses, so

\footnotetext{
industry characteristics at national level, which are minor or even trivial in firms in a province; and (iii) to allow good statistical control of the dataset, consisting of all observations within a geographical area, e.g., to prevent potential spatial autocorrelations increasing variances of disturbances if the analysis is conducted at cross-regional level.

${ }^{3}$ Binh Duong is always among the top three provinces with the highest PCI index (Provincial Competitiveness Index) (PCI, 2005; PCI, 2006; PCI, 2007; PCI, 2008). The PCI ranks the ability and willingness of provincial governments to develop businessfriendly environments for private sector development.
} 
final performance measures (profit, sales) reflect the over performance of all business units and from all income sources. For growth measures, an attempt was made to use growth of sales as a dependent variable to reflect a firm's performance, but the test for serial autocorrelation indicated significant violation of the assumption of no serial correlation, which seriously biases final findings with panel data. Therefore, although it is only one of several objectives of an enterprise, we focus on profitability as measure of firm performance.

Product diversification index: Gollop and Monahan (1991) list five properties of a diversification index. It must: (i) vary directly with the number of products; (ii) vary inversely with the increasingly unequal distribution of products across product lines; (iii) vary directly with the dissimilarity or heterogeneity of products; (iv) apply equally well to various scopes: plants, firms, and industries; and (v) be bounded between zero and unity. In this paper, we measure diversification by the entropy index (Appendix A), the most common and robust to all these five properties (Jacquemin and Berry, 1979). Segment information from SIC codes (Standard Industrial Classification) was used to construct it. The index is sensitive to changes in the number and distribution of products: it is bounded below by zero $(0 \leq E<\ln (n))$. As the number of products increases, the entropy index increases at a decreasing rate; but, as the distribution of products becomes more equal, it increases at an increasing rate. The index is 0 when the firm produces in only one industry (diversification is absent) and is equal to $\ln n$ in case the sales are equally distributed among $n$ industries.

Control variables: To isolate the relationship between product diversification and firm performance, one has to control for other variables that are likely to affect profitability. Since our aim is to isolate the effects of "product diversification" on performance, we introduce three categories of control variables: (i) individual level: educational attainment, age and gender of the owner; (ii) firm level: firm size, age, capital intensity, debt ratio, technological resources, and whether the firm exports its products / services; (iii) industry level: profitability proxied by average industry ROA (return on assets). The inclusion of these variables in the model is based on three streams of literature: industrial organization, management, and finance (Markides, 1995; Hitt et al., 1997; Qian, 2002; Santarelli and Tran, 2013).

- Technological resources: Grossmann (2007) indicates that technological resources are driving forces behind a positive relationship between product diversification and firm performance. It has been widely recognized that these may be measured through R\&D activities (for a review, see Audretsch, 1995): Indicators of R\&D inputs, such as R\&D investments and $R \& D$ personnel, indicators of $R \& D$ processes, e.g., number of hours devoted to R\&D, and indicators of R\&D outputs, e.g., number of patented inventions, or new product innovations introduced on the market. In this study, provided that protection of intellectual property rights is still inadequate in Vietnam, the rate of qualified R\&D teams and technical employees in the total labour force of firms is adopted as a proxy for their technological resources.

- Firm size: economic size and labour force size. Economic size is taken as the natural logarithm of total firm assets. A quadratic term is also added to establish a non-linear relationship between firm size and its performance. Labour force size is measured as the natural logarithm of the total number of employees. The logarithm transformation was used because size is highly skewed and extreme values strongly affect correlations with 
other variables. Firm size is normally used as a proxy for competitive position and firms' advantage within an industry (Johnson et al., 1997).

- Firm age: It is related to the level of experience, learning and managerial competencies that a firm accumulates. The age effect on firm performance is inconclusive and controversial, depending on the specific environment and industry where firms reside. In view of the dynamic features of an emerging market, aging may impede the ability of firms to be alert and capture profit opportunities with timeliness and efficiency. The effect of firm age is explored by means of the number of years that the firm has been in continuous operation.

- Capital intensity: Some firms are, by the nature of technology, more capital-intensive than others. Within any particular industry, a firm may choose a highly automated process or a more labour-intensive one. As Porter (1976) stated, capital intensity in the form of industry-specific assets acts as a barrier to exit. In general, capital intensity imposes a greater degree of risk, because assets are frozen in long-lived forms which may not be easy to be sold. Given that return (and risk) varies with capital intensity, differences in profitability are likely to be associated with capital intensity between diversified and undiversified firms. As Shepherd (1979) noted, there are several ways of measuring capital intensity, all showing similar patterns. The present study uses the ratio of net fixed assets to total number of employees.

- Debt ratio: the finance literature indicates that the leverage situation of firms strongly influences their value. On one hand, Opler and Titman (1994) found that highly leveraged firms lose a substantial market share to their more conservatively financed competitors. On the other hand, diversification can improve debt capacity, so reduce the chances of bankruptcy by going into new products / markets (Higgins and Schall, 1975), and improve asset deployment and profitability (Teece, 1982). Generally, the more debt in the firm's financial structure, the more volatile its earnings and the greater the risk to owners and creditors. Thus, the debt ratio, measured as the ratio of total debts to total assets, is adopted to isolate the effect of a firm's leverage capacity on its diversification / performance.

- Entrepreneurs' characteristics: we control for individual level characteristics of business owners by including three variables: gender, age and professional education of the entrepreneur. 'Gender' attains 1 if the entrepreneur is female; and 0 otherwise. 'Age' is the natural number of the entrepreneur's age. Professional education is a dummy attains 1 if she/he has a bachelor / master/ or PhD degree; and 0 otherwise.

- Average industry profitability: Since we include observations across multiple industries, it comes essential to consider industry average level performance. One of the motives for firms' diversification is when their core business has matured or started to decline or to reduce cyclical fluctuations in sales. The direction of their diversification will be those emerging industry with increasing profitable opportunities. The prevailing approaches to measure industry-level performance are either to include the industry average level of the particular performance measure (ROA, ROS, profit, etc.) as an independent variable (Tanriverdi and Venkatraman, 2005). Industry dummy variables, as an alternative for representing industry effects in a multi-industry study, seem like an elegant solution, since they provide a direct method for accounting for potential differences among industries without the trouble of parsing out which particular characteristics are most likely to be relevant. However, the significant increase of model variable reduces 
statistical power of the model, as well as fails to account for intra-industry or intra-sector differences (Sharp et al., 2013).This paper uses average ROA of all firms in the 2-digit industry as the proxy for industry profitability level.

Appendix A lists the variables adopted here, as well as how to measure/construct them and their descriptive statistics. Appendix B lists the pair-wise correlation matrix of the dependent variable and independent variables. We can see from the correlation matrix below, composed of 81 pair-wise correlations, that 66 are statistically significant. However, most of them are not numerically substantive with correlation coefficients below 0.3. Two substantive correlations which should be noted are the strong, positive correlation between ROS and ROI (0.7407) and economic size and labour size (0.6854). This is reasonable since both ROS and ROI are measures of firm profitability. Economic size and labour size are intuitively positively related.

\section{Estimation model}

We analyze firm diversification strategies and performance in three stages: decision (firms decide to diversify or not), degree (to what extent of relatedness firms will diversify once they decide to diversify), and outcome (the subsequent performance of firms given their diversification decision and diversification degree). We control for sample selection bias in the first two stages. We take into account the fact that either outperforming firms or underperforming firms may be more likely to undertake diversification than their counterparts. Lang and Stulz (1994) proposed the possibility of self-selection bias such that poor performers diversify in search of growth opportunities because they have exhausted such opportunities in their existing activities. Thus, diversification strategy is probably correlated with controlled observable firm characteristics and unobserved characteristics absorbed in error terms.

The endogeneity of diversification degree is controlled in stage 3 to account for firm characteristics that both lead to diversify, how much they would diversify and as well affect firm values. As pointed out by Campa and Kedia (2002), and Graham et al. (2002), diversified firms may trade at a discount not because diversification destroys value, but because undervalued firms tend to diversify. Thus, diversification is endogenous and the same sectors that cause firms to be undervalued may also cause them to diversify. Campa and Kedia (2002) propose that correcting for selection bias and endogeneity using panel data and fixed effects and two-stage selection models substantially reduces the observed discount. On the other hand, for the outcome of firms given their diversification strategies, it is plausible to assume that it takes some time until the payoff of firms' diversification is recognized. We propose two models, static and dynamic, in which the lagged dependent variable is included to isolate the effect of potential performance shock. For each model, we provide two specifications that treat the decision to diversify as exogenous and endogenously respectively to take into account those characteristics which lead firms to diversify and affect their value simultaneously.

Sample selection models have received a great deal of attention since the seminal work of Heckman (1974) on female labor supply. Traditionally, maximum likelihood procedures are applied to deal with the sample selection. However, the validity of such methods requires correct specification of the error distribution, which can be problematic in practice. The standard Heckman's (1979) two-stage method requires the normality assumption of error terms, which is too strong to hold in practice. In the past two decades, a number of parametric and 
semiparametric alternatives which do not require parametric specification of error distribution and functional form of heteroskedasticity have thus been proposed (Horowitz, 1992; Klein and Spady, 1993; Heckman and Smith 1995; Heckman et al., 1997). In a semiparametric approach, part of the functional form of the model, normally the selection equationis parametrically specified based upon plausible assumptions, while the rest of the model is not parameterized. While different semiparametric estimation methods to deal with sample selection have been proposed in theoretical literature, there has still been a lacuna in their applications to empirical problems in economics.

\subsection{Diversification equation}

The selection equation can be specified as follows:

$$
D I_{i t}=\left\{\begin{array}{l}
1 \text { if } D I_{i t}^{*}=w_{i t 1} \alpha_{1}+\varepsilon_{i t 1}>\bar{c} \\
0 \text { if } D I_{i t}^{*}=w_{i t} \alpha_{1}+\varepsilon_{i t 1} \leq \bar{c}
\end{array}\right.
$$

where $D I_{i t}$ is an observable indicator that takes value 1 if firm $i$ diversifies in year $t$, and 0 otherwise; $D I_{i t}^{*}$ is a latent variable reflecting firm's diversification effort such that firm $i$ decides to diversify if it is above a given threshold $\bar{c}, w_{i t 1}$ is a set of explanatory variables affecting the decision to diversify of firms, and $\varepsilon_{i t 1}$ is the error term.

Once the firm decides to diversify, the next decision point is the degree of diversification, i.e. the extent to which the new products / services are unrelated to the core product portfolio of the firm.

$$
\text { Entropy }_{i t}=\left\{\begin{array}{c}
D I_{i t}^{*}=w_{i t 2} \alpha_{2}+\varepsilon_{i t 2} \text { if } D I_{i t}=1 \\
0 \quad \text { if } D I_{i t}=0
\end{array}\right.
$$

$w_{i t 2}$ is a set of determinants of degree of relatedness of firm's diversification.

Under the selection rule described by (1) and (2), we have

$$
E\left(E_{n t r o p y} \backslash w_{i t 1}, w_{i t 2}, D I_{i t}>0\right)=w_{i t 2} \alpha_{2}+E\left(\varepsilon_{i t 2} \backslash \varepsilon_{i t 1}>-w_{i t 1} \alpha_{1}, w_{i t 1}, w_{i t 2}\right)
$$

The least squares method of regressing Entropy on $w_{2}$ is an inconsistent estimator of $\alpha_{2}$ if the second term on the right size of (3) is nonzero. If we are willing to assume that error terms in both (1) and (2) are $N(0, \infty)$. The standard Heckman $(1976,1979)$ two-stage method provides consistent estimators. Heckman suggests to restore a zero conditional mean by including an estimate of the selection bias term, $E\left(\varepsilon_{i t 2} \backslash \varepsilon_{i t 1}>-w_{i t 1} \alpha_{1}, w_{i t 1}, w_{i t 2}\right)$. Under normality assumption, this term is proportional to the inverse Mills ratio which can be estimated by probit or tobit from equation (1).

However, in many empirical problems, the distribution of the errors is not known or is subject to heteroskedasticity of unknown form. In such cases, the maximum likelihood estimator will not provide a consistent estimate (Goldberger, 1983). Also, for censored panel data with fixed effects, maximum likelihood estimation methods will generally be inconsistent even when the parametric form of the conditional error distribution is correctly specified (Honore, 1992). Thus, it is important to develop estimation methods that provide consistent estimates for sample selection dataset when the error distribution is non-normal or heteroskedastic. Vella $(1992,1998)$ and Wooldridge (1995) relax this assumption and propose the alternative two-stage estimation methods that may have better finite sample properties. 
Under the assumption that $\left.\varepsilon_{i t 1}, \varepsilon_{i t 2}\right)$ are independent of $\left.w_{i t 1}, w_{i t 2}\right)$, Vella and Wooldridge note that $E\left(\varepsilon_{i t 2} \backslash w_{i t 1}, w_{i t 2}, \varepsilon_{i t 1}, D I_{i t}>0\right)=E\left(\varepsilon_{i t 2} \backslash \varepsilon_{i t 1}, D I_{i t}>0\right)$. If one further assumes that $E\left(\varepsilon_{i t 2} \backslash \varepsilon_{i t 1}\right)=\gamma \varepsilon_{i t 1}$, then the selection bias correction term is $\gamma \varepsilon_{i t 1}$. We can estimate $\varepsilon_{i t 1}$ by $\widehat{\varepsilon_{t t 1}}=D I_{i t}-w_{i t 1} \widehat{\alpha_{1}}$, where $\widehat{\alpha_{1}}$ is the tobit or probit estimator of $\alpha_{1}$. Thus we can use $\varepsilon_{i t 1}$, rather than Heckman's (1979) inverse Mills ration, as an additional variable in the conditional expectation. There are two advantages of this method relatively to the standard Heckman procedure: (i) when $w_{i t 2}$ and the inverse Mills ratio are near collinearity, $\varepsilon_{i t 1}$ has more variation than $w_{i t 2}$, thereby making the Vella-Wooldridge estimator more stable and thus more efficient (see Wooldridge, 2002); (ii) the method is computationally less costly, relaxes the strong normality assumption, and more robust to near collinearity in data (Christofides et al., 2003).

It is plausible to assume that $E\left(\varepsilon_{i t 2} \backslash \varepsilon_{i t 1)}=g\left(\varepsilon_{i t 1}\right)\right.$, where $g($.$) is an unknown function. We$ can easily show that $E\left(E n t r o p y_{i t} \backslash w_{i t 1}, w_{i t 2}, \varepsilon_{i t 1}\right)=w_{i t 2} \alpha_{2}+g\left(\varepsilon_{i t 1}\right)$. Thuswehave

$$
\text { Entropy }_{i t}=w_{i t 2} \alpha_{2}+g\left(\varepsilon_{i t 1}\right)+v_{i t}
$$

Where $v_{i t}$ satisfies $E\left(v_{i t} \backslash \varepsilon_{i t 1}, D I_{i t}>0\right)=0$. Following Robinson (1988) and using the data with $D I_{i t}>0$, from (4) we can get

$$
\text { Entropy }_{i t}-E\left(\text { Entropy }_{i t} \backslash \varepsilon_{i t 1}\right)=\left[w_{i t 2}-E\left(w_{i t 2} \backslash \varepsilon_{i t 1}\right)\right] \alpha_{2}+v_{i t}
$$

Semykina and Wooldridge (2010) propose the correction for selection bias that allows form heterogeneously distributed and serially dependent error terms in both selection and primary equations. Since the method allows for a rather flexible structure of the error variance and do not impose any nonstandard assumptions on the conditional distributions of explanatory variables, it provides a useful alternative to existing approaches. Assuming the error term (1) as $\varepsilon_{i t 1}=c_{i 1}+$ $u_{i t 1}$, and in equation (2) as $\varepsilon_{i t 2}=c_{i 2}+u_{i t 2} ; c_{i 1}$ and $c_{i 2}$ are the unobserved fixed effects (maybe correlated with $\left.w_{i t 2}\right)$, and $u_{i t}$ is an idiosyncratic error. We assume that $E\left(u_{i t} \backslash w_{i 2}, c_{i}\right) \neq 0$ for some elements of $w_{i t 2}$. Further, assuming that $c_{i 1}=f\left(w_{i 1}\right)+a_{i 1}$, where $f($.$) is a known$ function, and $E\left(a_{i 1} \backslash w_{i 1}\right)=0$. Using a more flexible Chamberlain's (1980) specification, $c_{i 1}=f\left(w_{i 1}\right)+a_{i 1}=\bar{w}_{i 1} \theta_{1}+a_{i 1}$. Similarly, we also have $c_{i 2}=g\left(w_{i 1}\right)+a_{i 2}=\bar{w}_{i 1} \theta_{2}+$ $a_{i 2}$. This condition is similar to the within transformation and produces the fixed-effects slope estimators in balanced panel data. Combining with (2), we obtain:

$$
\begin{gathered}
\text { Entropy }_{i t}=w_{i t 2} \alpha_{2}+\bar{w}_{i 1} \theta_{1}+a_{i 1}+u_{i t 1}=w_{i t 2} \alpha_{2}+\bar{w}_{i 1} \theta_{1}+v_{i t 1} \\
=w_{i t 2} \alpha_{2}+\bar{w}_{i 1} \theta_{1}+\gamma E\left(v_{i t 2} \backslash w_{i 1}, D I_{i t}\right)+\epsilon_{i t}
\end{gathered}
$$

where $v_{i t 1} \equiv a_{i 1}+u_{i t 1}, v_{i t 2}=a_{i 2}+u_{i t 2}, E\left(\epsilon_{i t} \backslash w_{i 1}\right)=0$. With a slight abuse of notation, for $D I_{i t}=1,(6)$ can be written as

$$
\text { Entropy }_{i t}=w_{i t 2} \alpha_{2}+\bar{w}_{i 1} \theta_{1}+\gamma \lambda_{i t}+\epsilon_{i t}
$$

We estimate equation (7) in two stage: (i) For each year, use probit to estimate the equation: $P\left(D I_{i t}=1 \backslash w_{i 1}\right)=\phi\left(w_{i t 1} \alpha_{t 1}+\bar{w}_{i 1} \theta_{2}\right)$. Use the resulting estimates to obtain $\hat{\lambda}_{i t}$; (ii) For $D I_{i t}=1$, use pooled 2 SLS to estimate equation (7), where $\lambda_{i t}$ is replaced by $\hat{\lambda}_{i t}$, in which $w_{i t 1}, \bar{w}_{i 1}, \hat{\lambda}_{i t}$ are used as instruments. Interactions of $\hat{\lambda}_{i t}$ with year dummies are included as well to allow $\gamma$ to be different across $t$.

Propensity score approach has recently been adopted as an efficient way to address selection bias semipatrically (see Shadish et al. 2002 for a brief overview of propensity scores). This paper will follow Heckman and Smith (1995) and Heckman et al.'s (1998) to construct a regressionadjusted semiparametric conditional difference-in-differences matching estimator. In other words, propensity scores take into account all variables that might play a role in the selection 
process and create a predicted probability (i.e. propensity score) of diversification vs. nondiversification from a logistic regression equation and kernel-based matching. These scores then can be used to match diversification and non-diversification as a covariate in the main equation. The results from four estimation approaches: the standard Heckman's two-stage method, the Vella (1998) and Wooldridge (1995) parametric approach, the Semykina and Wooldridge (2010) model correcting for both endogeneity and selectivity, and the Heckman et al. (1998) kernelbased propensity score matching method, are reported in table 5.

Both parametric and semiparametric identification of sample selection model generally requires and "exclusion restriction" - that is, a regressor that is included in the set of regressors $w_{i t 1}$ for the binary variable $D I_{i t}$ (the selection equation) must be excluded from the list of $z_{i t}$ in the equation of interest (degree of diversification). This paper will adopt a dummy which indicates whether firmsare involved in export / import activities as the exclusion restriction. We believe that when conducting business transactions with foreign partners, firms will be more likely to decide to diversify their production in order to capture emerging demands from global market. However, the degree of their diversification activities will not be influenced by whether they export/import or not, but mainly by their production capacity and potentiality. The exclusion restriction test is presented in Table 1

Before estimating the selection model, we performed two tests for the presence of selection bias in the diversification degree equation. So far various tests have been proposed by Verbeek and Nijman (1992), Vella (1998), Wooldridge (1995), Das et al. (2003), Hsiao et al. (2008), and Semykina and Wooldridge (2010). While Verbeek and Nijman (1992), and Hsiao et al. (2008) propose the test for panel data models with exogenous explanatory variables, Semykina and Wooldridge (2010) use fixed effects to remove unobserved heterogeneity, and hence, permit arbitrary correlation between idiosyncratic errors and regressors. The test is based on the within transformation and has an importance advantage over alternative testing procedures because it is valid in the presence of arbitrary correlation between unobserved heterogeneity and explanatory variables. Given its novelty, we apply this test in three steps: (i) for each year, use probit to estimate $P\left(D I_{i t}=1 \backslash w_{i 1}\right)=\phi\left(w_{i t 1} \alpha_{1 t}+\bar{w}_{i 1} \beta_{t}\right)$. Use the resulting estimates to obtain the inverse Mills ratio $\hat{\lambda}_{i t} \equiv \lambda\left(w_{i t 1} \hat{\alpha}_{1 t}+\bar{w}_{i} \hat{\beta}_{t}\right)$; (ii) For $D I_{i t}=1$, use fixed-effect two-stage least squares (FE-2SLS) to estimate the equation: Entropy $y_{i t}=w_{i t 2} \alpha_{2}+\rho \hat{\lambda}_{i t}+\varepsilon_{i t 2}$ with $w_{i t 1}, \hat{\lambda}_{i t}$ as instruments. The interactions of $\hat{\lambda}_{i t}$ with year dummies are included as well to allow $\rho$ to be different across $t$; (iii) We use t-statistic to test $H_{0}: \rho=0$ for the significance of inverse Mills ratio, and the Wald test to test $H_{0}=\rho_{1}=\cdots=\rho_{T}=0$ for the significance of the interactions.

The second selection bias test we apply is the non-parametric test proposed by Das et al. (2003), and applied by Hall et al. (2009) in their innovation intensity equation. First, a random effect probit model is adopted for equation (1) with 'export' dummy as the exclusion restriction. Second, predicted probability of diversification from the first regression and the corresponding Mills' ratio are added in equation (2) as independent variables. Fixed effect least squares regression is adopted for the degree of diversification equation since we have a significant number of firms not diversifying (entropy=0). Selection bias is determined based on the significance of the predicted probabilities, the Mills' ratio, their squares and interaction. Results from the test for sample selection bias are present in table 1. 
Table 1: Sample selection test and exclusion restriction test for the variable "export"

\begin{tabular}{|l|l|}
\hline Relevance & \\
Das et al. (2003) test & $\chi^{2}(5)=25.35$ \\
Semykina and Wooldridge (2010) test & p-value 0.0001 \\
& $F_{\bar{\lambda}}(1,5555)=288$ \\
& p-value $=0.000$ \\
& $F_{\widehat{\lambda} * \text { i.year }}(5,5555)=24.89$ \\
& p-value =0.000 \\
\hline Quality test (correlated with regressors) & $\chi^{2}(1)=5.11$ \\
& p-value $=0.0238$ \\
\hline Validity test (exogeneitycondition) & $\chi^{2}(1)=1.72$ \\
& p-value $=0.19$ \\
\hline
\end{tabular}

The two sample selection tests indeed indicate the existence of selectivity issue in our panel data, which calls for relevant treatment with our estimation models reviewed above. The exclusion restriction test shows that "export" is a good exclusion since the firms' likelihood to export is significantly related to their propensity of diversification (quality test), but does not influence how much they will diversify once they are involved in diversification (validity test).

\subsection{Performance equation}

We consider both static and dynamic estimation models for the third stage of firms' diversification process, i.e. outcome. In the dynamic model, lagged dependent variable is included to isolate the effect of potential performance shock as well as to account for necessary time lag until the pay-off of diversification can be recognized. For each model, we provide two specifications with respect to whether diversification degree is treated as exogenous or endogenous. Although endogeneity bias is commonly confronted in cross-sectional studies, it is less frequently considered to be a source of concern in panel data estimation. This is partly due to the concept that fixed effects estimation eliminates most forms of unobserved heterogeneity (Verbeek and Nijman, 1992). However, Vella (1998) claims that certain forms of selection bias and heterogeneity cannot be eliminated with panel FE and RE models. The Durbin-Wu-Hausman test for endogeneity later justifies the need to isolate the endogeneity bias of diversification strategies.

The firm performance equation can be written as follows:

$$
\begin{gathered}
R O I_{i t}=R_{i t-1} \beta_{1}+\text { Entropy }_{i t} \beta_{2}+z_{i t} \beta_{3}+v_{i}+\epsilon_{i t} \\
(i=1,2, \ldots, n ; t=1,2, \ldots, T)
\end{gathered}
$$

In equation (8) above, $R O I_{i t-1}$ is the 1-year lagged value of return on investment of firm $i$ in year $t$. For the estimation of the static model, $R O I_{i t-1}$ is not included.Entropy $y_{i t}$ is the diversification index of firm $i . z_{i t}$ is a matrix of control individual-level, firm-level, and industrylevel characteristics. $v_{i}$ an unobserved firm-specific time-invariant effect which allows for heterogeneity in the means of the $R O I_{i t}$ series across firms, and $\epsilon_{i t}$ is a disturbance term. A key assumption maintained throughout this work is that the disturbances $\epsilon_{i t}$ are independent across individuals. We also treat the firm-effects $v_{i}$ as stochastic, which implies here that they are necessarily correlated with lagged dependent variable $R O I_{i t-1}$. 
Test for violations of estimation assumptions: $E\left(\epsilon_{i t} \epsilon_{i^{\prime} t^{\prime}}\right)=\left\{\begin{array}{ccc}\sigma_{\epsilon}^{2} & i=i^{\prime}, t=t^{\prime} & (H 1) \\ 0 & \text { otherwise } & (H 2)\end{array}\right.$

- Heteroskedasticity (H1) : the problem of heteroskedasticity is more prevalent in cross-sectional data, because they involve units and groups which are heterogeneous in nature. We apply the likelihood ratio test for heteroskedasticity in panel data and find out the strong existence of heteroskedasticity in our data. Thus, estimation with OLS is rejected, and the alternative estimation technique capable of correcting for heteroskedastic errors is "robust" regression method with standard errors corrected for heteroskedasticity by White's method.

Table 2 Test for Heteroskedasticity

\begin{tabular}{ll}
\hline \hline Heteroskedasticity test & ROI \\
\hline Likelihood ratio test & $\chi^{2}(929)=5522.95$ \\
& $\mathrm{p}$-value $=0.000$ \\
\hline \hline
\end{tabular}

- Serial correlation in time-series data (H2): the Wooldridge test for first-order autocorrelation in panel data is insignificant even at the $5 \%$ level, which indicates the absence of first-order serial correlation in the ROI equation. Serially correlated errors will give biased estimators with increasing variances of estimated coefficients. In this case, we can feel sure that ROI as the dependent variable satisfies the assumption of no serial correlation.

Table 3 Test for Serial Correlation

\begin{tabular}{ll}
\hline \hline Serial correlation test & ROI \\
\hline Wooldridge first-order & $\mathrm{F}(1,929)=3.195$ \\
serial correlation test & P-value =0.0728 \\
\hline \hline
\end{tabular}

- Endogeneity of diversification index: We consider the potential endogeneity of diversificationdegree; since we suspect that some unobserved individual-level and firm-level characteristics might influence both the firm's diversification decision and its subsequent profitability. The Durbin-Wu-Hausman test (see below) does indicate the strong presence of the endogeneity of diversification. The test begins with the reduced form regression, in which the assumed-endogenous diversification index is the dependent variable and all other observed exogenous firm-level characteristics are independent variables. The residuals predicted from this regression are then added into the structural equation (1). The endogeneity problem is determined according to the significance of the residual coefficient.

Table 4 Test for Endogeneity

\begin{tabular}{ll}
\hline \hline Durbin-Wu-Hausman test & $\chi^{2}(1)=25.04$ \\
& P-value $=0.0000$ \\
\hline \hline
\end{tabular}

Estimation methods: Several econometric problems may arise from estimating equation (8)

1. Diversification index Entropy Et $_{i t}$ is assumed to be endogenous.

2. Time-invariant unobserved firm characteristics (fixed effects) $v_{i}$ may be correlated with Entropy $i t$ and $z_{i t}$. 
3. The panel dataset has a short time dimension $(T=6)$ and a large number of firms $(n=$ 930). Thus, the presence of the lagged dependent variable $R O I_{i t-1}$ may give rise to autocorrelation, since it is correlated with fixed effects. It is therefore also treated as endogenous variable.

OLS estimators of $\beta$ are inconsistent, since explanatory variable $R O I_{i t-1}$ is positively correlated with error term $\left(v_{i}+\epsilon_{i t}\right)$ due to the presence of firm-effects, and this correlation does not vanish as the number of firms in the sample increases.

Within groups estimator eliminates this source of inconsistency by transforming the equation to eliminate $v_{i}$. However, for panels in which the number of time periods available is small, this transformation includes a non-negligible correlation between the transformed lagged dependent variable and the transformed error term: $R O I_{i t-1}-\frac{1}{T-1}\left(R O I_{i 1}+\cdots+R O I_{i T-1}\right)$ and $v_{i t}-\frac{1}{T-1}\left(v_{12}+\cdots+v_{i T}\right)$. Thus within groups estimator is also inconsistent here.

To solve problems 1 and 2, one would usually use fixed-effects instrumental variable estimation (2SLS), but this depends on the availability and validity of exogenous instruments. We therefore decided to use the Arellano-Bond (1991) difference GMM estimator, first proposed by Holtz-Eakin et al. (1988). The lagged levels of endogenous regressor Entropy ${ }_{i t}$ are used as instruments, which rise over time. This makes the endogenous variable pre-determined and thus not correlated with the error term in equation (8).

To cope with problem 2 (fixed effects), the differenced GMM uses first-differences to transform equation (8) into:

$$
\Delta R O I_{i t}=\beta_{1} \Delta R O I_{i t-1}+\beta_{2} \Delta \text { Entropy }_{i t}+\beta_{3} \Delta z_{i t}+\Delta \epsilon_{i t}
$$

By transforming the regressors by first differencing, the fixed firm-specific effect is removed, because it does not vary with time.

Lastly, to cope with problem 3, the Arellano-Bond estimator was designed for small-T and large-N panels. For the endogenous lagged dependent variable, the first-differenced lagged dependent variable is instrumented with its past levels.

Table 7 shows the estimation results from five estimation approaches: fixed-effects (FE) and random-effects (RE) model; instrumental-variable two-stage least-squares estimation (IV-2SLS) with GMM treatment for the static model; and the Arellano-Bond (1991) difference GMM estimator for the dynamic model. According to Baum and Schaffer (2003), generalized method of moments (GMM) estimation is more efficient than 2SLS when heteroskedasticity is present. Following Arellano-Bond (1991), the instrument for the endogenous diversification index is its one-period lagged value. This makes the endogenous variable pre-determined and, hence, not correlated with the error term in equation (8).

\section{Estimation Results and Discussion}

The estimation results for diversification decision and diversification degree of firms are given in Table 5 and 6 . These tables show a striking consistency in the general pattern of results obtained. Table 5 presents 4 estimation models: (i) first step probit of Heckman two-step consistent estimates; (ii) joint maximum likelihood estimation (MLE) based on the joint normality of $\left(\varepsilon_{i t}, e_{i t}\right)$; (iii) first step of Semykina and Wooldridge (2010) method; and (iv) kernel-based propensity matching method. 
Table 5: Probability of diversification decision

\begin{tabular}{|c|c|c|c|c|}
\hline \multirow[b]{2}{*}{ Variable } & \multirow[b]{2}{*}{$\begin{array}{l}\text { Heckman two- } \\
\text { step ( } 1^{\text {st }} \text { step } \\
\text { probit })\end{array}$} & \multicolumn{3}{|c|}{ Probability of diversification } \\
\hline & & $\begin{array}{c}\text { Joint MLE } \\
\left(1^{\text {st }} \text { step }\right)\end{array}$ & $\begin{array}{c}\text { Semykina and } \\
\text { Wooldridge (2010) } \\
\text { (stage } 1 \text { of } 2 \text { SLS) }\end{array}$ & $\begin{array}{l}\text { Heckman (1995) } \\
\text { Propensity } \\
\text { matching method }\end{array}$ \\
\hline \multirow[t]{2}{*}{ Firm age } & $0.0205^{* *}$ & $0.023 * *$ & $0.02 * *$ & $0.035 * *$ \\
\hline & $(0.004)$ & $(0.004)$ & $(0.004)$ & $(0.006)$ \\
\hline \multirow{2}{*}{ Firm's economic size } & 0.0385 & 0.052 & $0.333 * *$ & 0.098 \\
\hline & $(0.0844)$ & $(0.076)$ & $(0.084)$ & $(0.146)$ \\
\hline \multirow[t]{2}{*}{ Firm's economic size square } & -0.0032 & -0.004 & $-0.017 * *$ & -0.007 \\
\hline & $(0.0044)$ & $(0.004)$ & $(0.004)$ & $(0.007)$ \\
\hline \multirow[t]{2}{*}{ Firm's labour size } & $0.111 * *$ & $0.087 * *$ & $0.095 * *$ & $0.191 * *$ \\
\hline & $(0.021)$ & $(0.021)$ & $(0.025)$ & $(0.035)$ \\
\hline \multirow[t]{2}{*}{ Debt ratio } & $0.42 * *$ & $0.379 * *$ & $0.349 * *$ & $0.787 * *$ \\
\hline & $(0.071)$ & $(0.071)$ & $(0.088)$ & $(0.126)$ \\
\hline \multirow{2}{*}{ Capital intensity } & -0.0008 & -0.0001 & $-0.0001 *$ & -0.0001 \\
\hline & $(0.0008)$ & $(0.00006)$ & $(0.00005)$ & $(0.0001)$ \\
\hline \multirow[t]{2}{*}{ Technological resources } & $-0.281 *$ & -0.172 & $-0.465 *$ & $-0.489 *$ \\
\hline & $(0.134)$ & $(0.146)$ & $(0.217)$ & $(0.235)$ \\
\hline \multirow[t]{2}{*}{ Export Y/N } & $0.125 * *$ & $0.041 *$ & $0.128 *$ & $0.221 * *$ \\
\hline & $(0.047)$ & $(0.021)$ & $(0.062)$ & $(0.081)$ \\
\hline \multirow[t]{2}{*}{ Professional education Y/N } & $0.351 * *$ & $0.377 * *$ & $0.403 * *$ & $0.606 * *$ \\
\hline & $(0.0424)$ & $(0.040)$ & $(0.048)$ & $(0.073)$ \\
\hline \multirow[t]{2}{*}{ Gender } & $0.155 * *$ & $0.147 * *$ & 0.082 & $0.263 * *$ \\
\hline & $(0.047)$ & $(0.045)$ & $(0.055)$ & $(0.082)$ \\
\hline \multirow[t]{2}{*}{ Age } & $-0.0102 * *$ & $-0.007 * *$ & $-0.007 * *$ & $-0.0166^{* *}$ \\
\hline & $(0.002)$ & $(0.002)$ & $(0.002)$ & $(0.003)$ \\
\hline \multirow[t]{2}{*}{ Average industry ROA } & $-3.898 * *$ & $-3.879 * *$ & $-2.878 * *$ & $-7.078 * *$ \\
\hline & $(0.817)$ & $(0.873)$ & $(0.932)$ & $(1.471)$ \\
\hline \multirow[t]{2}{*}{$\hat{\lambda}$} & & & $0.666^{* *}$ & \\
\hline & & & $(0.148)$ & \\
\hline \multicolumn{2}{|l|}{$\hat{\lambda} *$ year dummies } & & $\chi^{2}(5)=399.32 * *$ & \\
\hline$\overline{w_{l}}$ & & & $\chi^{2}(9)=380.13 * *$ & \\
\hline \multirow[t]{2}{*}{ Intercept } & -0.15 & -0.316 & 0.07 & -0.111 \\
\hline & $(0.407)$ & $(0.364)$ & $(0.403)$ & $(0.705)$ \\
\hline Likelihood ratio test $\chi^{2}(12)$ & $240.17 * *$ & & & $242.33 * *$ \\
\hline Observations & 5580 & 5580 & 5580 & 5580 \\
\hline
\end{tabular}

Note: (*) significant at 5\% level; (**) significant at 1\% level; Standard errors in brackets

Both the Shapiro-Wilk W and the Shapiro-Francia W test for normality assumption of the error terms in diversification decision equation indicate the rejection of the null normality hypothesis at $1 \%$ significance level. Thus, the Heckman two-step procedure requiring normality assumption may not be an efficient estimation method for our analysis. If we compared estimation results across different methodological treatments in Table 5, sign of estimated parameters are quite consistent although the statistical significance seems to be stronger with coefficients obtained from the first stage of Semykina and Wooldridge (2010) approach. Note that the estimated equations here refer to the decision to diversify or not, rather than to the degree of diversification, so the estimated coefficients will carry a different meaning, i.e. the likelihood of undertaking a diversification policy.

There is consistency in significant effect of firm age, firms' labour size, debt ratio, technological resources, export, professional education, gender and age of firm owners and 
average industry ROA. Significant and positive parameters of debt ratio indicate the leverage effect of loans on stimulating firms' diversification activities. Technological resources proxied by the rate of technical employees in the whole labour force act as a barrier to firms' entering new business sector. It is likely that technical employees with specialized knowledge in the core business are less willing to absorb new knowledge and skills required for crossing firms' business boundaries, which is actually a significant source of change resistance in incumbent firms. We find evidences to support the quality test of 'export' as the exclusion restriction in sample selection treatment. Those firms exporting their products / services into foreign markets are more likely to undertake diversification in order to capture emerging demands, advanced technology and resources from international markets.

Table 6: Diversification degree of firms

\begin{tabular}{|c|c|c|c|c|}
\hline \multirow[b]{2}{*}{ Variable } & \multicolumn{4}{|c|}{ "Degree of diversification (Entropy index) } \\
\hline & $\begin{array}{l}\text { Heckman } \\
\text { two-step }\end{array}$ & Joint MLE & $\begin{array}{c}\text { Semykina and } \\
\text { Wooldridge (2010) } \\
\text { 2SLS }\end{array}$ & $\begin{array}{c}\text { Vella and } \\
\text { Wooldridge } \\
(1994)\end{array}$ \\
\hline Firm age & $\begin{array}{l}0.0149 * \\
(00065)\end{array}$ & $0.013 * *$ & $\begin{array}{c}0.002 \\
(0.002)\end{array}$ & $\begin{array}{l}0.028 * * \\
(0.002)\end{array}$ \\
\hline Firm's economic size & $\begin{array}{c}0.181 * * \\
(0.066)\end{array}$ & $\begin{array}{c}0.171 * * \\
(0.076)\end{array}$ & $\begin{array}{l}0.151 * * \\
(0.0405)\end{array}$ & $\begin{array}{c}0.087 * * \\
(0.032)\end{array}$ \\
\hline Firm's economic size square & $\begin{array}{c}-0.0095 * * \\
(0.0035)\end{array}$ & $\begin{array}{c}-0.009 * * \\
(0.003)\end{array}$ & $\begin{array}{c}-0.007 * * \\
(0.002)\end{array}$ & $\begin{array}{c}-0.0093 * * \\
(0.0017)\end{array}$ \\
\hline Firm's labour size & $\begin{array}{l}-0.034 \\
(0.033)\end{array}$ & $\begin{array}{c}-0.044 * * \\
(0.013)\end{array}$ & $\begin{array}{c}-0.025 * * \\
(0.011)\end{array}$ & $\begin{array}{c}-0.144 * * \\
(0.011)\end{array}$ \\
\hline Debt ratio & $\begin{array}{l}0.193 \\
(0.13)\end{array}$ & $\begin{array}{c}0.193 * * \\
(0.045)\end{array}$ & $\begin{array}{l}0.08 * * \\
(0.027)\end{array}$ & $\begin{array}{c}0.702 * * \\
(0.041)\end{array}$ \\
\hline Capital intensity & $\begin{array}{c}-0.001 \\
(0.0008)\end{array}$ & $\begin{array}{l}-0.0006 \\
(0.0004)\end{array}$ & $\begin{array}{l}-0.0002 \\
(0.0004)\end{array}$ & $\begin{array}{l}-0.0001 * * \\
(0.00008)\end{array}$ \\
\hline Technological resources & $\begin{array}{c}0.074 \\
(0.127)\end{array}$ & $\begin{array}{c}0.007 \\
(0.097)\end{array}$ & $\begin{array}{c}0.251 * * \\
(0.073)\end{array}$ & $\begin{array}{l}0.82 * * \\
(0.063)\end{array}$ \\
\hline Professional education $\mathrm{Y} / \mathrm{N}$ & $\begin{array}{l}0.242^{*} \\
(0.105)\end{array}$ & $\begin{array}{l}0.221 * * \\
(0.028)\end{array}$ & $\begin{array}{c}0.0363 * \\
(0.02)\end{array}$ & $\begin{array}{l}0.102 * * \\
(0.0206)\end{array}$ \\
\hline Gender & $\begin{array}{l}0.111^{*} \\
(0.058)\end{array}$ & $\begin{array}{c}0.118 * * \\
(0.029)\end{array}$ & $\begin{array}{l}0.015 \\
(0.02)\end{array}$ & $\begin{array}{c}0.263 * * \\
(0.022)\end{array}$ \\
\hline Age & $\begin{array}{l}-0.0013 \\
(0.0032)\end{array}$ & $\begin{array}{l}-0.037 * * \\
(0.0015)\end{array}$ & $\begin{array}{c}-0.004 * * \\
(0.001)\end{array}$ & $\begin{array}{c}-0.008 * * \\
(0.001)\end{array}$ \\
\hline Average industry ROA & $\begin{array}{l}-2.218^{*} \\
(1.219)\end{array}$ & $\begin{array}{c}-2.018 * * \\
(0.59)\end{array}$ & $\begin{array}{l}-1.987^{*} \\
(0.928)\end{array}$ & $\begin{array}{c}-2.759 * * \\
(0.362)\end{array}$ \\
\hline$\hat{\lambda}$ & $\begin{array}{l}0.711^{*} \\
(0.365)\end{array}$ & & $\begin{array}{c}-0.136 * * \\
(0.033)\end{array}$ & \\
\hline$\hat{\lambda}^{*}$ year dummies & & & $\chi^{2}(5)=10.7 *$ & \\
\hline$\widehat{\varepsilon_{l t}}$ & & & & $\begin{array}{l}1.497 * * \\
(0.059)\end{array}$ \\
\hline Intercept & $\begin{array}{c}0.281 \\
(0.456)\end{array}$ & $\begin{array}{l}0.504 * \\
(0.25)\end{array}$ & $\begin{array}{c}0.07 \\
(0.403)\end{array}$ & $\begin{array}{c}-1.781 * * \\
(0.184)\end{array}$ \\
\hline $\begin{array}{l}\text { Wald } \\
\text { LR }\end{array}$ & $\chi^{2}(11)=31.05^{* *}$ & $\begin{array}{c}\chi^{2}(11)=130 . \\
28^{* *}\end{array}$ & $\chi^{2}(17)=98.28 * *$ & $\chi^{2}(13)=5555^{* *}$ \\
\hline Observations & 5580 & 5580 & 5580 & $\begin{array}{l}5580 \text { (1186 } \\
\text { uncensored) }\end{array}$ \\
\hline
\end{tabular}

Note: (*) significant at 5\% level; (**) significant at 1\% level; Standard errors in brackets 
With respect to the effects of individual-level characteristics on the likelihood of firm diversification, significant impact could be found for all three control variables: other factors remain constant, firms having higher educated owners, or female owners, or younger owners are more likely to diversify than their counterparts. Finally, we witness the negative relationship between industry profitability, proxied by average industry ROA, and firms' diversification decision. Apparently, firms facing low profitable opportunities in their own industry will have to search for opportunities in other industries: one of the motives for firms' diversification activities is to compensate for their loss or poor performance in their core business.

We again observe the consistency in the general pattern of results obtained. It is worth noting that the effects of some variables, for instance technological resources and firm size, in this equation contradict with their effects in the above diversification decision equation, which indicates that factors stimulating firms to diversify do not necessarily influence their diversification degree to the same extent and vice versa. Firm age is statistically positively related to degree of diversification of firms. Older firms with accumulating knowledge and experience tend to take risks of expanding their product portfolio generously rather than stay persistently within their core business. Economic size of firms, as expected, positively stimulates their diversification activities. Firms possessing larger asset pool have more favourable conditions to invest in $\mathrm{R} \& \mathrm{D}$, and hence, are more incentivised to bring up radical innovations. However, the effect of economic size on the firm's diversification intensity is nonlinearly decreasing to scale. Further increase of total asset to a certain level will not create the proportional positive effect on the likelihood that firms diversify into unrelated knowledge base. However, firm labour force size has a statistically negative impact on firms' relatedness of diversification although it has a stimulating effect on firms' likelihood to diversify: larger firm size on one hand facilitates firms' diversification activities by transferring a part of their rich human capital into other business sectors, but on the other hand impedes the diversification into unrelated business activities which require higher degree of flexibility and responsiveness of business units. This is because there has been no evidence that large firms considered in the analysis undertake their diversification policy by creating independent business units. Finally, debt ratio and technological resources both significantly stimulate firms to increase their involvement in areas unrelated or just marginally related to their current domain of competence and corresponding opportunity set. Technical employees do not encourage firms to enter new business sectors; but once firms overcome this change resistance by taking part in some forms of diversification, they act as a stimulative source for firms to take risks in joining unrelated industries. Consistent with above findings, owners who are more educated, or female, or younger are more likely to go into unrelated diversification. We also find the negative relationship between industry profitability and firms' degree of diversification. Firms may want to get out of their stagnant industry by diversifying into a completely new industry.

Table 7 lists the estimation results for both static and dynamic models. The former adopts panel-data estimation: fixed-effects and random-effects regressions when diversification is assumed exogenously; and the GMM technique when it is assumed endogenously. The latter adopts differenced GMM estimation and measures diversification exogenously and endogenously respectively. Given the panel data structure and diagnosis tests performed above, the dynamic model with GMM treatment is the preferable estimation, based on which results are interpreted. 
Table 7: Firm performance (ROI as the dependent variable)

\begin{tabular}{|c|c|c|c|c|c|}
\hline & \multicolumn{5}{|c|}{ Firm return on investment (ROI) } \\
\hline & \multicolumn{3}{|c|}{$\begin{array}{l}\text { Static model } \\
\quad R O I_{i t}=E_{\text {Entropy }} \beta_{1}+z_{i t} \beta_{2}+v_{i}+\epsilon_{i t}\end{array}$} & \multicolumn{2}{|c|}{$\begin{array}{l}\text { Dynamic model } \\
\quad R O I_{i t} \\
\quad=R O I_{i t-1} \beta_{1}+\text { Entropy }_{i t} \beta_{2} \\
\quad+z_{i t} \beta_{3}+v_{i}+\epsilon_{i t}\end{array}$} \\
\hline & $\mathrm{FE}^{1}$ & $\mathrm{RE}^{1}$ & $\mathrm{GMM}^{2}$ & $\begin{array}{l}\text { GMM } \\
\text { exogenous }\end{array}$ & $\begin{array}{l}\text { GMM } \\
\text { endogenous }\end{array}$ \\
\hline $\mathrm{ROI}(\mathrm{t}-1)$ & & & & $\begin{array}{l}0.375 * * \\
(0.068)\end{array}$ & $\begin{array}{l}0.364 * * \\
(0.062)\end{array}$ \\
\hline Entropy & $\begin{array}{l}0.595 * * \\
(0.121)\end{array}$ & $\begin{array}{l}0.267 * * \\
(0.052)\end{array}$ & $\begin{array}{l}0.255 * * \\
(0.0411)\end{array}$ & $\begin{array}{l}0.798 * * \\
(0.188)\end{array}$ & $\begin{array}{l}0.78 * * \\
(0.18)\end{array}$ \\
\hline Entropysquared & $\begin{array}{l}-0.257 * * \\
(0.094)\end{array}$ & $\begin{array}{l}-0.073 \\
(0.056)\end{array}$ & $\begin{array}{l}-0.085^{*} \\
(0.043)\end{array}$ & $\begin{array}{l}-0.38 * * \\
(0.133)\end{array}$ & $\begin{array}{l}-0.369 * * \\
(0.129)\end{array}$ \\
\hline Technologicalresources & $\begin{array}{l}0.046^{*} \\
(0.025)\end{array}$ & $\begin{array}{l}0.006 \\
(0.02)\end{array}$ & $\begin{array}{l}0.007 \\
(0.021)\end{array}$ & $\begin{array}{l}0.042 \\
(0.056)\end{array}$ & $\begin{array}{l}0.0448 * \\
(0.056)\end{array}$ \\
\hline Leverage (debt ratio) & $\begin{array}{l}-0.056^{* *} \\
(0.0214)\end{array}$ & $\begin{array}{l}-0.068 * * \\
(0.015)\end{array}$ & $\begin{array}{l}-0.083 * * \\
(0.011)\end{array}$ & $\begin{array}{l}-0.118 * * \\
(0.036)\end{array}$ & $\begin{array}{l}-0.116^{* *} \\
(0.036)\end{array}$ \\
\hline Capital intensity & $\begin{array}{l}-0.0002 \\
(0.0002)\end{array}$ & $\begin{array}{l}-0.0004 \\
(0.00001)\end{array}$ & $\begin{array}{l}-0.0001 * * \\
(0.00005)\end{array}$ & $\begin{array}{l}-0.0001 \\
(0.0001)\end{array}$ & $\begin{array}{l}-0.0001 \\
(0.0001)\end{array}$ \\
\hline Export & $\begin{array}{l}0.025 * * \\
(0.0064)\end{array}$ & $\begin{array}{l}0.032 * * \\
(0.0057)\end{array}$ & $\begin{array}{l}0.0349 * * \\
(0.0052)\end{array}$ & $\begin{array}{l}0.034 * * \\
(0.011)\end{array}$ & $\begin{array}{l}0.035^{* *} \\
(0.011)\end{array}$ \\
\hline Firmage & $\begin{array}{l}0.0008 \\
(0.0008)\end{array}$ & $\begin{array}{l}0.0005 \\
(0.0006)\end{array}$ & $\begin{array}{l}0.0002 \\
(0.0004)\end{array}$ & $\begin{array}{l}0.0006 \\
(0.001)\end{array}$ & $\begin{array}{l}0.0007 \\
(0.001)\end{array}$ \\
\hline Economicsize & $\begin{array}{l}-0.098 * \\
(0.051)\end{array}$ & $\begin{array}{l}-0.087 * * \\
(0.033)\end{array}$ & $\begin{array}{l}-0.084 * * \\
(0.0185)\end{array}$ & $\begin{array}{l}-0.145^{*} \\
(0.06)\end{array}$ & $\begin{array}{l}-0.144 * \\
(0.061)\end{array}$ \\
\hline Economicsizesquared & $\begin{array}{l}0.0053 * \\
(0.0025)\end{array}$ & $\begin{array}{l}0.004 * * \\
(0.0017)\end{array}$ & $\begin{array}{l}0.0043 * * \\
(0.0009)\end{array}$ & $\begin{array}{l}0.008 * \\
(0.003)\end{array}$ & $\begin{array}{l}0.007 * \\
(0.003)\end{array}$ \\
\hline Laborsize & $\begin{array}{l}0.022 * * \\
(0.0062)\end{array}$ & $\begin{array}{l}0.0049 \\
(0.0038)\end{array}$ & $\begin{array}{l}0.005^{*} \\
(0.0027)\end{array}$ & $\begin{array}{l}0.0088 \\
(0.011)\end{array}$ & $\begin{array}{l}0.009 \\
(0.011)\end{array}$ \\
\hline Professioneducation $\mathrm{Y} / \mathrm{N}$ & $\begin{array}{l}0.170 * * \\
(0.011)\end{array}$ & $\begin{array}{l}0.125 * * \\
(0.008)\end{array}$ & $\begin{array}{l}0.083 * * \\
(0.005)\end{array}$ & $\begin{array}{l}0.14 * * \\
(0.016)\end{array}$ & $\begin{array}{l}0.14 * * \\
(0.016)\end{array}$ \\
\hline Gender & & $\begin{array}{l}0.025^{*} \\
(0.01)\end{array}$ & $\begin{array}{l}0.024 * * \\
(0.0065)\end{array}$ & & \\
\hline Age & $\begin{array}{l}-0.003^{*} \\
(0.0017)\end{array}$ & $\begin{array}{l}-0.0003 \\
(0.0003)\end{array}$ & $\begin{array}{l}-0.0001 \\
(0.0002)\end{array}$ & $\begin{array}{l}-0.002 \\
(0.002)\end{array}$ & $\begin{array}{l}-0.003 \\
(0.02)\end{array}$ \\
\hline Averageindustry ROS & $\begin{array}{l}0.018 \\
(0.089)\end{array}$ & $\begin{array}{l}0.066 \\
(0.078)\end{array}$ & $\begin{array}{l}0.128^{*} \\
(0.061)\end{array}$ & $\begin{array}{l}0.108 \\
(0.088)\end{array}$ & $\begin{array}{l}0.101 \\
(0.089)\end{array}$ \\
\hline Intercept & $\begin{array}{l}0.462 * \\
(0.241) \\
\end{array}$ & $\begin{array}{l}0.399 * \\
(0.157)\end{array}$ & $\begin{array}{l}0.426 * * \\
(0.087)\end{array}$ & $\begin{array}{l}0.685^{*} \\
(0.324) \\
\end{array}$ & $\begin{array}{l}0.698^{*} \\
(0.328) \\
\end{array}$ \\
\hline F-value & $\begin{array}{l}\mathrm{F}(13) \\
=29.04 * *\end{array}$ & & $\begin{array}{l}\mathrm{F}(14) \\
=45.75^{* *}\end{array}$ & & \\
\hline Wald Chi-sq & & $\begin{array}{l}\chi^{2}(13)= \\
408.23^{* *}\end{array}$ & & $\begin{array}{l}\chi^{2}(14)= \\
295.15^{* *}=\end{array}$ & $\begin{array}{l}\chi^{2}(14)= \\
309.74 * *\end{array}$ \\
\hline Hausman test & & $229 * *$ & & & \\
\hline $\begin{array}{l}\text { Hansen J statistic } \\
\text { of excluded instruments }\end{array}$ & & & $\begin{array}{l}\chi^{2}(1)=3 \\
\mathrm{P}=0.072\end{array}$ & & \\
\hline Observations & 5580 & 5580 & 4650 & 3720 & 3720 \\
\hline
\end{tabular}

Notes: $(* *):$ significant at 1\% level; (*): significant at 5\% level; Standard errors in brackets

1: FE and RE estimators assume that the diversification index is exogenous. 2: GMM estimators assume that the diversification index is endogenous. 3: The differenced GMM estimator assumes that all explanatory variables, apart from the lagged dependent variable, are exogenous; robust standard errors are used to control for heteroskedasticity and serial correlation. 4: The differenced GMM estimator assumes that the diversification index and lagged dependent variable are endogenous; robust standard errors are used. 
From Table 7, we can see that the coefficients of lagged ROI are statistically significant in both regressions, which indicates the superiority of the dynamic model with endogeneity treatment of entropy index. It is plausible that ROI has significant lag effect since firms base their investment decision this year contingent on the investment return of last year. The ROS equation is placed in Appendix C. In general, both ROS and ROI equations show substantial consistency in the pattern of regressor significance and size of coefficients. For the analysis of estimation results, we base our interpretation on the ROI equation. Due to the significant of lagged ROI, the dynamic model with GMM treatment is the better estimation technique. The Hausman test also indicates the superiority of the dynamic model with ROI as the dependent variable at $1 \%$ significance level ${ }^{4}$.

We first discuss the estimation results from $\mathrm{FE}$ and $\mathrm{RE}$ regressions in which diversification is measured exogenously. The criteria for selecting the RE or FE model is often based on whether $\operatorname{cor}\left(v_{i}, X\right)=0$. The Hausman test with the null hypothesis thatcor $\left(v_{i}, X\right)=0$ can be rejected, whichindicates that the RE model is preferable.

With ROI as the measure of profitability, both FE/RE and GMM estimations tend to find a positive relationship between entropy index and firm performance. Generally, more highly focused firms tend to have lower profitability or, equivalently, greater diversification raises profitability. In other words, positive effects occur as firms move from a single-business strategy to a diversification strategy. However, the significant parameters of the square of the entropy index indicate the non-linear influence of diversification: the positive effects of diversification gradually fall as the firm moves further and further away from its core business. These findings support our hypothesis and are consistent with most of those summarized by Palich et al. (2000). Based on previous evidences, they conclude that performance increases as firms move from single-business strategies to low-scaled diversification, but that the effect deteriorates as firms move away from the low end of related diversification to the high end of unrelated diversification. As Qian (1997) suggests, the relative costs and benefits of product diversification are likely to depend on how different business activities of a firm are related to each other. If they are loosely linked or poorly structured, they are less likely to complement or supplement each other, and hence, synergy will not exist.

Obviously, the profitability of a firm can mainly be accelerated by increasing innovativeness through its accumulated technological resources. According to resource-based theory, a manufacturing firm's technology resources are valuable assets for its survival and development and can differentiate its performance. Thus, it is not surprising that the number of R\&D and technical personnel as a proxy of technological resources of a firm has a strong positive effect on its profitability.

The relation between corporate performance and the debt-to-assets ratio has long been established in corporate finance literature (McConnel and Servaes, 1990; Lang et al., 1991; Harford, 1999). According to this paradigm, capital structure choice is a trade-off between the

\footnotetext{
${ }^{4} \chi^{2}=50.58$
}

p-value $=0.000$ 
costs and benefits of debt. Although there is agreement among academics and practitioners on the benefits of debt, it may be argued that large firms are more likely to receive more benefits than medium-sized or small firms, at the same level of debt ratio. While loans significantly stimulate firms to be involved in diversification activities, their burden imposes a serious impediment to firm value, especially for small and medium-sized firms. Therefore, it is plausible that debt ratio is estimated to have statistical negative effect on firm profitability.

We find a significantly convex relation between the economic size of firms in terms of total assets and their investment return. Larger firms realize lower return on investment than their smaller counterparts. Owners tend to face more challenges in allocating resources efficiently in large firms. It is worth noting that the majority of total assets of firms in Vietnam are fixed assets including land, machinery, equipments, etc. Their "asset specificity" made them difficult to be transferable to other business sectors (high transaction cost); and thus imposes a limitation in diversification pay-off, and in turn outcome that large firms can obtain. This tends to limit the firm's economic size to the extent that owners-managers achieve optimum efficiency. We do find the significant effect of quadratic coefficient of economic size to indicate a curvilinear influence on performance. Those firms exporting their products / services are likely to outperform their non-exporting counterparts. Finally, with respect to individual characteristics of owners, consistent with our previous finding (Santarelli and Tran, 2013) and a number of studies on the return to education (for instance, Cooper et al., 1994; Parker and Van Praag, 2006), professional education has a significant and positive effect on firm performance. We do not find evidences for a significant impact of industry profitability on firm performance.

\section{Conclusions}

Research tends to focus on performance outcomes of types and degrees of diversification rather than on what determines diversification in the first place (Hoskisson and Hitt, 1990; Doving and Gooderham, 2008). Although researchers share a common consensus that diversification is to deploy surplus resources and cash flows, they still fail to account for the antecedents of resource deployment, and in turn of diversification decision. Various approaches, resting on differing assumptions, justify divergent relationships. However, these assumptions all converge in dealing with conflicting demands of synergies and responsiveness with respect to diversification. Their investigation will enable us to understand whether diversification has a positive or negative effect on firm performance. Empirical results seem to be consistent with a resource- (or competence)-based view, which maintains that a positive relationship between diversification and profitability depends on the relatedness of diversified activities. However, as the driving forces of diversification and its profitable pay-off are resources or prior competences underlying diversification decision, it is still not clear what factors determine firms' decision to diversify and to what degree (relatedness of their activities).

This paper is pioneer in investigating firm diversification in a transition country in three interrelated and consecutive stages: decision, degree, and outcome. Controlling for individuallevel, firm-level, and industry-level characteristics we find out that (i) factors stimulating firms to undertake diversification decision do not necessarily influence their diversification degree to the same extent of sign and magnitude; (ii) firms with higher debt ratio are more likely to diversify and diversify with stronger degree; (iii) export firms have more opportunities to recognize diversification activities, but do not necessarily diversify at stronger degree than non- 
export firms; (iv) diversification has a curvilinear effect on firm-level profitability: product diversification improves firms' profit up to a point, after which a further increase in diversification is associated with declining performance; (v) higher educated entrepreneurs are more likely to diversify, undertake stronger diversification strategy, and produce higher performance for their firms; (vi) low industry profitability significantly stimulates firms to diversify into other business sectors, but does not have any impact on their overall performance.

We make extensive and integrated use of recent methodological developments in analyzing diversification strategies and their outcome for the population of private firms in a dynamic Vietnamese province. Particularly, we take into account the sample selection and endogeneity issues from correlated disturbances by applying different advanced parametric and semiparametric estimation methods for both static and dynamic treatments of firm-level panel data. Initially, sample selectivity will be tested and corrected by four estimation approaches, the standard Heckman's two-stage method, the Vella (1998) and Wooldridge (1995) parametric approach, the Semykina and Wooldridge (2010) model correcting for both endogeneity and selectivity, and the Heckman et al. (1998) kernel-based matching in a binary choice selection equation determining whether or not the firm diversifies. Conditional on its diversification decision, we observe its diversification degree (the extent of relatedness to the firm's core business). Then endogeneity of diversification degree will be controlled in the performance equation since unobserved individual-level and firm-level characteristics might influence both firms' diversification decision and their subsequent profitability (given their diversification decision and diversification degree choice). We apply the GMM and Arellano-Bond (1991) difference GMM estimation approach for both static and dynamic treatment. We rely our analysis on the dataset of the whole population of firms in Binh Duong, the most competitive province in Vietnam after excluding state-owned and foreign firms, which is extracted from the annual enterprise survey of Vietnam General Statistics House.

From a policy perspective, it is important to ascertain level and degree of product diversification. In the case of SMEs with limited resources to sustain large-scale R\&D operations, they might need support for adopting a "deep niche" strategy by concentrating resources on a few specialized products and services (Qian, 2002: 612). For large firms with complex multidivisional structures, they might need to rely on highly skilled workers or managerial competences to overcome those constraints in terms of organizational efficiency and corporate governance which represent the primary challenge impeding firms' diversification degree or product scope. 
Appendix A: Dependent and independent variables

\begin{tabular}{|c|c|c|c|c|c|c|c|c|}
\hline Categories & Indicators & Variables & Measure & Obs. & Mean & $\begin{array}{l}\text { Std. } \\
\text { Dev. }\end{array}$ & Min & $\operatorname{Max}$ \\
\hline \multirow{5}{*}{$\begin{array}{l}\text { Dependent } \\
\text { variable and } \\
\text { explanatory } \\
\text { variable }\end{array}$} & \multirow{2}{*}{ Accounting measures } & $\begin{array}{l}\text { ROS: Return on } \\
\text { sales }\end{array}$ & ROS $=\frac{\text { Operating profit }}{\text { Total sales }}$ & 5580 & 0.0207 & 0.2101 & -1 & 1 \\
\hline & & $\begin{array}{l}\text { ROI: Return on } \\
\text { investment }\end{array}$ & $R O I=\frac{\text { Operating profit }}{\text { Annual investment }}$ & 5580 & 0.0429 & 0.1702 & -1 & 1 \\
\hline & \multirow{3}{*}{ Diversificationindex } & Diversification & $\begin{array}{l}\text { The dummy attains } 1 \text { if the firm diversifies, } 0 \\
\text { otherwise }\end{array}$ & 5580 & 0.212 & 0.409 & 0 & 1 \\
\hline & & \multirow[t]{2}{*}{$\begin{array}{l}\text { Entropyindex } \\
\text { (E) }\end{array}$} & $\begin{array}{l}T D=\sum_{i}^{n} S_{i} \ln \left(1 / S_{i}\right) \text { where } S_{i} \text { is the share of } \\
\text { segment } i \text { in the firm's sales, and } \ln \left(1 / S_{i}\right) \text { is the } \\
\text { weight for each segmenti. }\end{array}$ & 5580 & 0.096 & 0.2323 & 0 & 1.598 \\
\hline & & & Square of entropyindex & 5580 & 0.0631 & 0.207 & 0 & 2.556 \\
\hline \multirow{8}{*}{$\begin{array}{l}\text { Control } \\
\text { variables: } \\
\text { firm-level } \\
\text { charateristics }\end{array}$} & \multirow{3}{*}{ Firmsize } & Labor force size & Natural $\log$ of total number of employees & 5580 & 4.261 & 1.561 & 0 & 9.419 \\
\hline & & \multirow{2}{*}{ Economicsize } & Natural log of total assets & 5580 & 9.261 & 1.823 & 0 & 15.471 \\
\hline & & & Square of natural log of total assets & 5580 & 89.109 & 34.221 & 0 & 239.35 \\
\hline & Firmage & Firmage & Number of years firm has been operating & 5580 & 6.268 & 4.856 & 1 & 60 \\
\hline & Technologicalresources & R\&D personnel & $\begin{array}{l}\text { The rate of technical personnel in total firm labor } \\
\text { force }\end{array}$ & 5580 & 0.097 & 0.175 & 0 & 1 \\
\hline & Financial leverage & Debt ratio & Debt ratio $=\frac{\text { Total debt }}{\text { Total assets }}$ & 5580 & 0.391 & 0.306 & 0 & 1 \\
\hline & \multirow[t]{2}{*}{ Capital intensiveness } & Capital intensity & Capital intensity $=\frac{\text { Fixed assets }}{\text { Number of employees }}$ & 5580 & 291.92 & 1595.5 & 0 & 20000 \\
\hline & & Export & $\begin{array}{l}\text { The dummy attains } 1 \text { if the firm exports its } \\
\text { products / services }\end{array}$ & 5580 & 0.241 & 0.428 & 0 & 1 \\
\hline \multirow{3}{*}{\multicolumn{2}{|c|}{$\begin{array}{l}\text { Control variables } \\
\text { characteristics }\end{array}$}} & $\begin{array}{l}\text { Professional } \\
\text { education }\end{array}$ & $\begin{array}{l}\text { The dummy attains } 1 \text { if the entrepreneur has } \\
\text { bachelor / master } / \mathrm{PhD} \text { degree }\end{array}$ & 5580 & 0.376 & 0.484 & 0 & 1 \\
\hline & & Gender & $\begin{array}{l}\text { The dummy attains } 1 \text { if the entrepreneur is } \\
\text { female }\end{array}$ & 5580 & 0.205 & 0.404 & 0 & 1 \\
\hline & & Age & Age of the entrepreneur & 5580 & 47.203 & 9.658 & 20 & 77 \\
\hline $\begin{array}{l}\text { Control } \\
\text { variable: } \\
\text { industry-level }\end{array}$ & Industry performance & $\begin{array}{l}\text { Averageindustry } \\
\text { ROA }\end{array}$ & $\frac{1}{n} \sum_{i}^{n} \frac{\text { Operating profit }}{\text { Total assets }_{i}}$ & 5580 & 0.0299 & 0.035 & -0.053 & 0.7832 \\
\hline
\end{tabular}

Note: SIC industries at four-digit level are treated as industry segments; at two-digit level are treated as industry group 
Appendix B: Correlation matrix of dependent and independent variables

\begin{tabular}{|c|c|c|c|c|c|c|c|c|c|c|c|c|c|c|}
\hline & ROI & ROS & Entro & $\begin{array}{c}\text { Firm } \\
\text { age }\end{array}$ & Export & $\begin{array}{l}\text { Debt } \\
\text { ratio }\end{array}$ & $\begin{array}{l}\text { Capital } \\
\text { intensity }\end{array}$ & $\begin{array}{l}\text { Labor } \\
\text { size }\end{array}$ & $\begin{array}{l}\text { Eco. } \\
\text { Size }\end{array}$ & $\begin{array}{c}\text { Technical } \\
\text { employ. }\end{array}$ & $\begin{array}{l}\text { Pro. } \\
\text { Educ }\end{array}$ & Gender & Age & $\begin{array}{c}\text { Industry } \\
\text { ROA }\end{array}$ \\
\hline ROI & 1.0000 & & & & & & & & & & & & & \\
\hline ROS & $0.740 *$ & 1.0000 & & & & & & & & & & & & \\
\hline Entropy & $0.278^{*}$ & $0.262 *$ & 1.0000 & & & & & & & & & & & \\
\hline Firm age & $0.069 *$ & $0.112^{*}$ & $0.067^{*}$ & 1.0000 & & & & & & & & & & \\
\hline Export & $0.126^{*}$ & $0.141 *$ & 0.0268 & $0.105^{*}$ & 1.0000 & & & & & & & & & \\
\hline $\begin{array}{l}\text { Debt } \\
\text { ratio }\end{array}$ & $-.128 *$ & $-.083^{*}$ & $0.063 *$ & $-.061^{*}$ & $0.089 *$ & 1.0000 & & & & & & & & \\
\hline $\begin{array}{l}\text { Capital } \\
\text { intensity }\end{array}$ & $-.035^{*}$ & $-.072 *$ & -0.006 & $-.092 *$ & $-.045^{*}$ & $-.075^{*}$ & 1.0000 & & & & & & & \\
\hline $\begin{array}{l}\text { Labor } \\
\text { size }\end{array}$ & $0.056^{*}$ & 0.0369 & 0.0015 & $0.065^{*}$ & $0.281 *$ & $0.376^{*}$ & $-0.248^{*}$ & 1.0000 & & & & & & \\
\hline $\begin{array}{l}\text { Econo } \\
\text { size }\end{array}$ & $0.075^{*}$ & $0.055^{*}$ & 0.0274 & 0.0231 & $0.257 *$ & $0.477 *$ & $0.123 *$ & $0.685^{*}$ & 1.0000 & & & & & \\
\hline $\begin{array}{l}\text { Technial } \\
\text { employee }\end{array}$ & 0.0182 & -0.007 & 0.0307 & $-.106 *$ & -.0074 & -.0064 & $0.5075^{*}$ & $-.263^{*}$ & $0.153^{*}$ & 1.0000 & & & & \\
\hline Pro. Educ & $0.242 *$ & $0.281^{*}$ & $0.128 *$ & 0.0108 & $0.250 *$ & $0.175^{*}$ & -0.0198 & $0.189^{*}$ & $0.293^{*}$ & $0.1662 *$ & 1.0000 & & & \\
\hline Gender & $0.066^{*}$ & $0.056^{*}$ & $0.044 *$ & -0.025 & $-.038^{*}$ & $-.066^{*}$ & -0.0282 & $-.170 *$ & $-.200 *$ & $-0.039 *$ & $-0.077 *$ & 1.0000 & & \\
\hline Age & 0.0003 & -.0149 & -.0211 & $0.302 *$ & 0.0183 & $-.089 *$ & $-0.036^{*}$ & $0.043^{*}$ & -.0076 & $-0.106^{*}$ & $-0.088^{*}$ & $-.151 *$ & 1.000 & \\
\hline $\begin{array}{c}\text { Industry } \\
\text { ROA }\end{array}$ & $0.047^{*}$ & 0.0057 & $-.045^{*}$ & $0.097 *$ & $0.092 *$ & 0.0069 & 0.0081 & $0.052 *$ & $0.116^{*}$ & $0.063^{*}$ & $0.0614 *$ & $-.095 *$ & $.056^{*}$ & 1.0000 \\
\hline
\end{tabular}


Appendix C: Firm performance (ROS as the dependent variable)

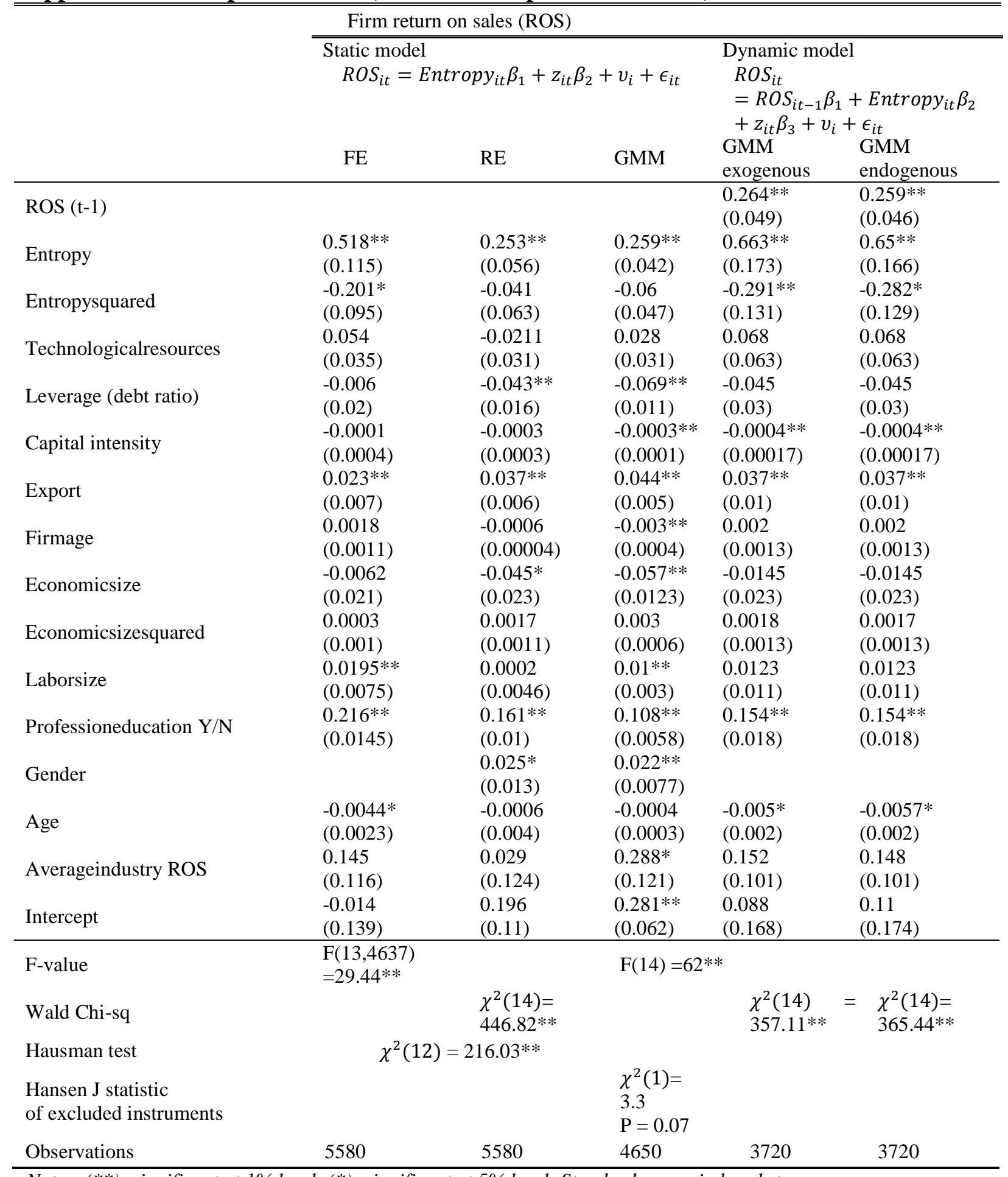

Notes: (**): significant at 1\% level; (*): significant at 5\% level; Standard errors in brackets 


\section{References}

Andrews, K. R. (1980), The Concept of Corporate Strategy, Homewood, IL: Richard D. Irwin.

Ansoff, H. (1965), Corporate Strategy, New York: McGraw-Hill.

Arellano, M. and Bond, S. (1991). "Some Tests of Specification for Panel Data: Monte Carlo Evidence and An Application to Employment Equations," Review of Economic Studies, 58 (2), 277-297.

Arnould, R. J. (1969). "Conglomerate Growth and Profitability," in Economics of Conglomerate Growth, eds. L. Garoian, Corvallis, Oregon, Oregon State University, pp. 72 - 80.

Audretsch, D.B. (1995), Innovation and Industry Evolution. MIT Press: Cambridge, MA.

Barney, J. B. (1986), "Strategic Factor Markets: Expectation, Luck, and Business Strategy," Management Science, 32(10), 1231-1241.

Baum, F. C. and Schaffer, M. E. (2003), "Instrumental Variables and GMM: Estimation and Testing," The Stata Journal, 3(1), 1-31.

Bernheim, D. and Whinston, M. (1990), "Multimarket Contact and Collusive Behavior," Rand Journal of Economics, 21(1), 1-26.

Berry, C. H. (1975), Corporate Growth and Diversification, Princeton, NJ: Princeton University Press.

Bhide, A. (1990), "Reversing Corporate Diversification,” Journal of Applied Corporate Finance, 3(2), 70-81.

Campa, J.M. and Kedia, S. (2002), "Explaining the Diversification Discount," The Journal of Finance, 57(4), 17311762.

Chandler, A. D. (1962), Strategy and Structure, MIT Press: Cambridge, MA.

Christensen, H. K. and Montgomery, C. A. (1981), "Corporate Economic Performance: Diversification Strategy versus Market Structure," Strategic Management Journal, 2(4), 327-344.

Christensen, J. F. and Foss, N. J. (1997), "Dynamic Corporate Coherence and Competence-based Competition: Theoretical Foundations and Strategic Implications," in Competence-based Strategic Management, eds. A. Heene and R. Sanchez, New York, NY: John Wiley \& Sons Ltd, pp. 287-312.

Chistofides, L. N., Li, Q., Liu, Z. And Min, I. (2003), "Recent Two-Stage Sample Selection Procedures With an Application to the Gender Wage Gap," Journal of Business and Economic Statistics, 21(3), 396-405.

Coase, R. H. (1937), “The Nature of the Firm," Economica, 4 (16), 386-405.

Cohen, W. M. and Klepper, S. (1992), "The Anatomy of R\&D Intensity Distributions," American Economic Review, 82(4), 773-799.

Cooper, A. C., Gimeno-Gascon, F. J. and Woo, C. Y. (1994), "Initial Human and Financial Capital as Predictors of New Venture Performance," Journal of Business Venturing, 9(5), 371-395.

Das, M., Newey, W. K. and Vella, F. (2003), "Nonparametric Estimation of Sample Selection Models," Review of Economic Studies, 70(1), 33-58.

Datta, D., Rajagopalan, N. and Rasheed, A. (1991), "Diversification and Performance: Critical Review and Future Directions," Journal of Management Studies, 28(5), 529-558.

Deeds, D., Decarolis, D. and Coombs, J.E. (1998), "Firm-specific Resources and Wealth Creation in High Technology Ventures: Evidence from Newly Public Biotechnology Firms," Entrepreneurship Theory and Practice, 22(3), 55-74.

Dess, G. G., Ireland, R. D., Zahara, S. A., Floyd, S. W., Janney, J. I. and Lane, P. J. (2003), "Emerging Issues in Corporate Entrepreneurship," Journal of Management, 29(3), 351-378.

Doving, E. and Gooderham, P. N. (2008), "Dynamic Capabilities as Antecedents of the Scope of Related Diversification: the Case of Small Firm Accountancy Practices," Strategic Management Journal, 29(8), 841857.

Farjoun, M. (1994), "Beyond Industry Boundaries: Human Expertise, Diversification and Resource-Related Industry Groups," Organization science 5(2), 185-199.

Foss, N. J. and Christensen, J. F. (2001), “A Market-process Approach to Corporate Coherence,” Managerial and Decision Economics. 22 (4-5), 213-226.

Geringer, J. M., Beamish, P. W. and daCosta, R. C. (1989), "Diversification Strategy and Internationalization: Implications for MNE Performance," Strategic Management Journal. 10(2), 109-119.

Goldberger, A. S. (1983), "Abnormal Selection Bias", in Studies in Econometrics Time Series, and Multivariate Statistics, eds. S. Karlin, T. Amemiya and L. A. Goodman, New York: Academic Press, pp. 67-84.

Gollop, F. M. and Monahan, J. L. (1991), "A Generalized Index of Diversification: Trends in U.S. Manufacturing”, Review of Economics and Statistics, 73(2), 318-330.

Gort, M. (1962), Diversification and Integration in American Industry, Princeton: Princeton University Press. 
Graham, J., Lemmon, M. and Wolf, J. (2002), “Does Corporate Diversification Destroy Value?” Journal of Finance 57(2), 695-720.

Grant, R. M. (1988), “On 'Dominant Logic', Relatedness and the Link between Diversity and Performance," Strategic Management Journal, 9(6), 639-642.

Grossmann, V. (2007), "Firm Size and Diversification: Multiproduct Firms in Asymmetric Oligopoly," International Journal of Industrial Organization, 25(1), 51-67.

Hall, B. H., Lotti, F., and Mairesse, J. (2009), "Innovation and Productivity in SMEs: Empirical Evidence for Italy," Small Business Economics. 33(1), 13-33.

Harford, J. (1999), “Corporate Cash Reserves and Acquisitions,” Journal of Finance, 54(6), 1969-1997.

Heckman, J. (1974), "Shadow Prices, Market Wages, and Labor Supply," Econometrica. 42(4), 679-693.

Heckman, J. (1979), "Sample Selection Bias as Specific Error," Econometrica. 47(1), 152-161.

Heckman, J. J. and Smith, J. A. (1995), “Assessing the Case for Social Experiments," Journal of Economic Perspective, 9 (2), 85-110.

Heckman, J. J., Ichimura, H. and Todd, P. (1998), "Matching as An Econometric Evaluation Estimator," Review of Economic Studies, 65 (2), 261-294.

Heckman, J., Ichimura, H. and Todd, P. E. (1997), "Matching as an Econometric Evaluation Estimator: Evidence from Evaluating a Job Training Programme," Review of Economic Studies, 64, 605-654.

Higgins, R.C. and Schall, L.D. (1975), “Corporate Bankruptcy and Conglomerate Merger," Journal of Finance, 30(1), 93-113.

Hitt, M.A., Hoskisson, R.E. and Kim, H. (1997), "International Diversification: Effects on Innovation and Firm Performance in Product-diversified Firms," Academy of Management Journal, 40(4), 767-798.

Holtz-eakin, D., Newey, W. and Rosen, H. S. (1988), "Estimating Vector Autoregressions with Panel Data," Econometrica, 56(6), 1371-1395.

Honore, B. E. (1992), “Trimmed LAD and Least Squares Estimation of Truncated and Censored Regression Models with Fixed Effects," Econometrica, 60(3), 533-565.

Horowitz, J. L. (1992), "A Smoothed Maximum Score Estimator for the Binary Response Model," Econometrica, $60(3), 505-531$.

Hoskisson, R. E. and Hitt, M. A. (1990), “Antecedents and Performance Outcomes of Diversification: A Review and Critique of Theoretical Perspectives," Journal of Management, 16(2), 461-509.

Hsiao, C., Shen, Y., Wang, B. and Weeks, G. (2008), "Evaluating the Effectiveness of Washington State Repeated Job Search Services on the Employment Rate of Prime-age Female Welfare Recipients," Journal of Econometrics, 145(1), 98-108.

Iacobucci, D. and Rosa, P. (2005), "Growth, Diversification, and Business Group Formation in Entrepreneurial Firms," Small Business Economics, 25(1), 65-82.

Jacquemin, A. P. and Berry, C. H. (1979), "Entropy Measure of Diversification and Corporate Growth,” Journal of Industrial Economics, 27 (4), 359-369.

Johnson, J.H., Lenn, D.G. and O’Neill, H.M. (1997), "Many Paths Across Nations: How Business Level Strategies Influence the Extent of Internationalization of MNCs in the US Construction Equipment Industry," Journal of Global Business, 8(15), 33-43.

Jones, G. R. and Hill, C. W. L. (1988), "Transaction Cost Analysis of Strategy-structure Choice," Strategic Management Journal, 9(2), 159-172.

Kamien, M. I. and Schwartz, N. L. (1975), "Market Structures and Innovation: A Survey," Journal of Economic Literature, 13 (1), 1-37.

Klein, P. G. and Lien, L. B. (2009), "Diversification, Industry Structure, and Firm Strategy: An Organizational Economics Perspective," in Economic Institutions of Strategy (Advances in Strategic Management, Volume 26, eds. J. A. Nickerson and B. S. Silverman, Emerald Group Publishing Limited, pp. 289-312.

Klein, R. W. and Spady, R. H. (1993), "An Efficient Semiparametric Estimator for Binary Response Models," Econometrica, 61(2), 387-421.

Lang, L. H. P. and Stulz, R. M. (1994), “Tobin's q, Corporate Diversification, and Firm Performance,” Journal of Political Economy, 102 (6), 1248-1280.

Lang, L., Stulz, R. and Walkling, R. (1991), “A Test of the Free Cash Flow Hypothesis: the Case of Bidder Returns," Journal of Financial Economics, 29(2), 315-335.

Lien, L. B. and Klein, P.G. (2006), "Relatedness and Acquirer Performance," in Advances in Mergers and Acquisitions, vol. 5, eds. G. L. Cooper and S. Finkelstein, Amsterdam: Elsevier, pp. 9-24.

Luo, Y. (2002), "Product Diversification in International Joint Ventures: Performance Implications in An Emerging Market," Strategic Management Journal, 23(1), 1-20. 
Maksimovic, V. and Phillips, G. (2002), "Do Conglomerate Firms Allocate Resources Inefficiently Across Industries? Theory and Evidence," Journal of Finance, 57 (2), 721-767.

Markham, J. W. (1973), Conglomerate Enterprise and Economic Performance, Cambridge Mass.: Harvard University Press.

Markides, C. C. (1992), "Consequence of Corporate Refocusing: Ex ante Evidence," Academy of Management Journal, 35(2), 398-412.

Markides, C. C. (1995), "Diversification, Restructuring, and Economic Performance," Strategic Management Journal, 16(2), 101-118.

Markides, C. C. and Williamson, P. J. (1994), "Related Diversification, Core Competences and Corporate Performance," Strategic Management Journal, 15(S2), 149-165.

McConnell, J. J. and Servaes, H. (1990), “Additional Evidence on Equity Ownership and Corporate Value," Journal of Financial Economics, 27(2), 595-612.

Montgomery, C. A. (1985), "Product Market Diversification and Market Power," Academy of Management Journal, 28(4), 789-798.

Montgomery, C. A. (1994), "Corporate Diversification,” The Journal of Economic Perspectives, 8(3), 163-178.

Montgomery, C. A. and Wernerfelt, B. (1988), "Diversification, Ricardian rents, and Tobin's q," Rand Journal of Economics, 19(4), 623-632.

Murphy, G. B., Trailer, J. W. and Hill, R. C. (1996), "Measuring Performance in Entrepreneurship," Journal of Business Research, 36(1), 15-23.

Nachum, L. (1999), "Diversification Strategies of Developing Country Firms," Journal of International Management, 5(2), 115-140.

Opler, T. C. and Titman, S. (1994), "Financial Distress and Corporate Performance," Journal of Finance, 49(3), 1015-1040.

Palich, L. E., Cardinal, L. B. and Miller, C. C. (2000), "Curvilinearity in the Diversification Performance Linkage: An Examination of Over Three Decades of Research", Strategic Management Journal, 21 (2), 155-174.

Parker, S. C. and Van Praag, C. M. (2006), "Schooling, Capital Constraints, and Entrepreneurial Performance: The Endogenous Triangle," Journal of Business and Economic Statistics, 24, 416-431.

PCI. (2005) (2006) (2007) (2008), “The Vietnam Provincial Competitive Index," Vietnam Competitive Initiative (VNCI) Policy Paper No. 10, 11, 12 \& 13. http://www.vnci.org/publications.html.

Penrose, E. (1959), The theory of the growth of the firm, Oxford: Blackwell.

Piga, C. A. and Vivarelli, M. (2004), "Internal and External R\&D: A Sample Selection Approach," Oxford Bulletin of Economics and Statistics, 66(4), 457-482.

Porter, M. (1976), "Please Note Location of Nearest Exit: Exit Barriers and Strategic and Organizational Planning," California Management Review, 19(2), 21-33.

Prahalad, C. K and Bettis, R. A. (1986), "The Dominant Logic: A New Linkage between Diversity and Performance," Strategic Management Journal, 7(6), 485-501.

Qian, G. (1997), “Assessing Product-market Diversification of US Firms," Management International Review, 37(2), 127-149.

Qian, G. (2002), "Multinationality, Product Diversification, and Profitability of Emerging US Small- and Mediumsized Enterprises," Journal of Business Venturing, 17 (6), 611-633.

Robins, J. and Wiersema, M. F. (1995), “A Resource-based Approach to the Multibusiness Firm: Empirical Analysis of Portfolio Interrelationships and Corporate Financial Performance," Strategic Management Journal, 16(4), 277-299.

Robinson, P. (1988), “Root-N-Consistent Semiparametric Regression”, Econometrica, 56(4), 931-954.

Rumelt, R. P. (1974), Strategy, Structure, and Economic Performance, Cambridge MA: Harvard University Press.

Rumelt, R. P. (1982), "Diversification Strategy and Profitability,” Strategic Management Journal, 3(4), 359-369.

Salter, M. S. and Weinhold, W. A. (1981), "Choosing Compatible Acquisitions," Harvard Business Review, 59, 117-127.

Santarelli, E. and Tran, H. T. (2013), "The Interplay of Human and Social Capital in Shaping Entrepreneurial Performance: the Case of Vietnam," Small Business Economics, 40(2), 435-458.

Scott, J. (1993), Purposive Diversification and Economic Performance, Cambridge University Press.

Semykina, A. and Wooldridge, J. (2010), "Estimating Panel Data Models in the Presence of Endogeneity and Selection," Journal of Econometrics, 157 (2), 375-380.

Shadish, W. R., Cook, T. D. and Campbell, D. T. (2002), Experimental and Quasi-experimental Designs for Generalized Causal Inference. Boston, MA: Houghton Mifflin.

Sharp, B. M., Bergh, D. D. and Li, M. (2013), "Measuring and Testing Industry Effects in Strategic Management 
Research: An Update, Assessment, and Demonstration," Organizational Research Methods, 16(1), 43-46.

Shepherd, W. G. (1979), The Economics of Industrial Organization, Englewood Cliffs, N.J., Prentice Hall.

Silverman, B. S. (1999), "Technological Resources and the Direction of Corporate Diversification: Toward an Integration of the Resource-Based View and Transaction Cost Economics," Management Science, 45(8), 1109-1124.

Spagnolo, G. (1999), “On Interdependent Supergames: Multimarket Contact, Concavity and Collusion,” Journal of Economic Theory, 89(1), 127-139.

Tallman, S. and Li, J. (1996), "Effects of International Diversity and Product Diversity on the Performance of Multinational Firms," Academy of Management Journal, 39(1), 179-196.

Tanriverdi, H. and Venkatraman, N. (2005), "Knowledge Relatedness and the Performance of Multibusiness Firms," Strategic Management Journal, 26(2), 97-119.

Teece, D. J. (1980), "Economies of Scope and the Scope of the Enterprise," Journal of Economic Behavior and Organization, 1(3), 223-247.

Teece, D. J., Rumelt, R., Dosi, G. and Winter, S. (1994), "Understanding Corporate Coherence: Theory and Evidence, Journal of Economic Behavior and Organization, 23(1), 1-30.

Teece, D.J. (1982), “Towards an Economic Theory of the Multiproduct Firm," Journal of Economic Behavior and Organization, 3(1), 39-63.

Tran, H. T. and Zaninotto, E. (2012), "Product Diversification, Corporate Entrepreneurship and Firm Performance: An Empirical Study of Vietnamese Firms," in Prodotto, consumatore, e politiche di mercato quarant'anni dopo, eds. S. Borghini, A. Caru, F. Golfetto, S. Pace, D. Rinallo, L. Visconti and F. Zerbini, Egea S.p.A: Milan, pp. 407-428.

Vannoni, D. (2000), "Diversification, the Resource View and Productivity: Evidence from Italian Manufacturing Firms," Empirica, 27(1), 47-63.

Vannoni, D. (2004), "Causes and Effects of Multimarket Activity from Theory to Empirical Analysis," Managerial and Decision Economics, 25(3), 163-174.

Vella, F. (1992), "Simple Tests for Sample Selection Bias in Censored and Discrete Choice Model," Journal of Applied Econometrics, 7, 413-421.

Vella, F. (1998), “Estimating Models with Sample Selection Bias: A Survey,” Journal of Human Resources, 33 (1), 127-169.

Verbeek, M. and Nijman, T. (1992), “Testing for Selectivity Bias in Panel Data Models," International Economic Review, 33(3), 681-703.

Williamson, O. E. (1985), Economic Institutions of Capitalism, Free Press: New York.

Wit, B. D. and Meyer, R. (2005), Strategy Synthesis, London: Non Basic Stock Line.

Wooldridge, J. M. (1995), Selection Corrections for Panel Data Models under Conditional Mean Independence Assumptions, Journal of Econometrics, 68 (1), 115-132.

Wooldridge, J. M. (2002), Econometric Analysis of Cross-Section and Panel Data, Cambridge, MA: MIT Press. 


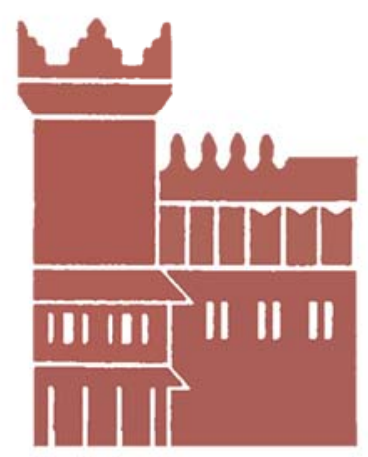

Alma Mater Studiorum - Università di Bologna DEPARTMENT OF ECONOMICS

Strada Maggiore 45

40125 Bologna - Italy

Tel. +39051 2092604

Fax +390512092664

http://www.dse.unibo.it 